Volume 4, Issue 2 (Summer 2012)

\title{
The Amsterdam Guild of Saint Luke in the 17th Century
}

I.H.van Eeghen (Jasper Hillegers, translator)

Recommended Citation:

I.H. van Eeghen (Jasper Hillegers, translator), The Amsterdam Guild of Saint Luke in the Seventeenth Century" JHNA 4:2 (Summer 2012), DOI:10.5092/jhna.2012.4.2.4

Available at https://jhna.org/articles/amsterdam-guild-of-saint-luke-17th-century/

Published by Historians of Netherlandish Art: https://hnanews.org/

Republication Guidelines: https://jhna.org/republication-guidelines/

Notes: This PDF is provided for reference purposes only and may not contain all the functionality or features of the original, online publication. This is a revised PDF that may contain different page numbers from the previous version. Use electronic searching to locate passages. This PDF provides paragraph numbers as well as page numbers for citation purposes.

ISSN: 1949-9833 


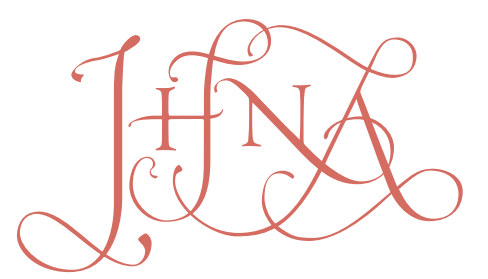

JOURNAL OF HISTORIANS OF NETHERLANDISH ART

\section{THE AMSTERDAM GUILD OF SAINT LUKE IN THE 17TH CENTURY}

\section{I.H. van Eeghen}

Here we present the first translation of this valuable article from Dutch into English. The loss of the St. Luke Guild's documents in the early nineteenth century had created a significant lacuna in the historical record. Van Eeghen endeavored to fill this gap by creatively combing through multiple archival sources - anything she could find - from City Orphanage and Burgomaster archives to funerary medallions and much more. Because of her authoritative knowledge of such archival records, both published and in manuscript, she was able to provide an impressive amount of new information about the guild's operations, while also expanding our view of the social fabric that was crucial for the well-being of Amsterdam artists. Among other things, we learn about the guild's attempts to protect members against imports, and about its wider efforts to control the art market by forging connections with civic authorities and related guilds. Published in 1969, the $300^{\text {th }}$ anniversary of Rembrandt's death, the article also contains information specific to his activities. In a section on auctions and their operations, it includes details about the auctioneers who conducted sales of Rembrandt's goods between 1655 and 1658. The article has long proven helpful to art historians studying the socio-economic circumstances of art. In fact, it served as an important resource for Eric Jan Sluijter's article "On Brabant Rubbish, Economic Competition, Artistic Rivalry, and the Growth of the Market for Paintings in the First Decades of the Seventeenth Century,"JHNA 1:2 (2009), the first article that JHNA published in translation. In making the present translation, we have kept as close as feasible to the original text, in order to capture the flavor of van Eeghen's writing style. At the same time, we have tried to render the article readable in English, corrected some factual errors, and added new information where appropriate. The bibliography and notes contain many additional titles. The original Dutch text can be accessed via a PDF (see web article). D0I: 10.5092/jhna.2012.4.2.4

$\mathrm{t}$ the beginning of the nineteenth century a tremendous tidying up must have taken
place in the chamber of the Guild of Saint Luke in the Weighing House [the Waag, where
the guild's archives were kept]. Whoever had the unfortunate idea and what exactly disappeared is not known. We only know that by 1829 nothing survived from the period before 1750. ${ }^{1}$ Interest in precisely this artists' guild remains huge, however. It thus seems to be a good idea to record here what can be traced back from other sources about this guild from the famous seventeenth century. [Given the gap in the records] this will not be a definitive article, but hopefully it will prove useful nevertheless. In honor of the Rembrandt Year [1969] I have included a lot of facts relating to Rembrandt as examples of the proceedings. Readers will see for themselves that a large number of errors have been corrected and that even some unknown matters have come to light. They must bear in mind that I could have done the same for any random artist of the time. 
F. D. O.Obreen, who collected a great deal of facts about the various Guilds of Saint Luke in his Archief, had to make do with the printed guild ordinances of 1789 . Now these give a very complete and well-ordered overview of the ordinances that could be found for that year, divided up in terms of subject matter; but as a result of this division, the chronological order becomes unclear. Sometimes items are inaccurate or not recorded. The latter also applies to the portfolio from the eighteenth century compiled by the lawyer Herman Noordkerk. ${ }^{2}$ Finally, I wish to mention here the publication by Johannes Gerard van Dillen, which goes no further than $1632 .{ }^{3}$

3 The oldest printed ordinances of the Guild of Saint Luke date from 1720. They were intended for distribution among the guild members. Prior to this, in common with most other guilds, guild members just asked the guild's overseers [overlieden] if they wanted to know something. One written copy of the ordinances from the mid-seventeenth century still exists in the archive of the booksellers' guild, which separated from the Guild of Saint Luke in 1662. The booksellers had already been considering plans to leave the Guild of Saint Luke and had probably copied the ordinances with this in mind. This was done on October 19, 1657, by the notary C. Tou. On January 9, 1663 -- thus after the separation -- this copy was validated (gewaarmerkt) by the notary G. Steeman. ${ }^{4}$

Regarding this ordinance, I present only some lesser-known or unknown details. In order to shed more light I would like to make clear that when considering these ordinances one must bear two points in mind. First, these ordinances or regulations (keuren) did not just simply appear but rather each addition or change was a response to some specific event or problem. Sometimes we are lucky enough to know what the causes were. This is especially the case in the eighteenth century, since more sources are available. In the seventeenth century, the reason for a regulation can often only be guessed at. Second, one must constantly bear in mind that the guild was composed of varied and diverse professions and crafts. A new regulation was frequently intended -- even if this was not expressed in so many words -- not for all groups, but only for a few or sometimes even a single group within the guild. ${ }^{5}$

\section{Members of the Guild}

In 1579, after the separation of the Guild of Saint Luke from the Onze Lieve Vrouwe, or stone masons' guild, the following groups of members were listed: "painters, glassmakers, sculptors, engravers, embroiderers, tapestry makers, pottery bakers, and suchlike others who earn their living with brush or paint" (schilders, glasemaekers, beeldesnijders, figuersnijders, borduyrwerckers, tapissierwerckers ende leywerckers, mitsgaders alle andere die haer metter pentsier, ofte metter venve generen). Then there were also "all those who worked with a press" or "with paint, pencil, brush, with which one applies paint, and metal by which one grinds glass" (alle de gheene die hem mette pers generen ... mette verwe, pintseel, borstel, daer men de verwe mede verstroyt ende ijser, daer men 't glas mede gruyst), who had to pay a single fee of three guilders to the guild, the so-called "buyers of the guild membership" (gildekopers). It is understandable that problems arose with such vague descriptions. In 1621, a clearer formulation was found: "that everyone who falls under the arts or the Guild of Saint Luke, namely painters, sellers of art, glass makers, embroiderers and sellers thereof, bookbinders and sellers thereof, sculptors, engravers and figure cutters, tapestry workers, compass makers, potters, coffin makers, including all others who work with pencil, 
brush or with paint, will not be allowed to exercise their profession in this city, unless they first become citizens and burghers (porters) of this city, and will have paid the guild in full" (dat alle de geene, die onder de kunst oft 't gilde van St Lucas sijn, als namentlijk schilders, vercopers van dien, glasemaeckers, borduyrwerkers ende vercopers van dien, boekebinders ende vercopers van dien, beeltsnijders, plaet- ende figuersnijders, tapitsierwerckers, compassemaekers, glaywerckers, coffermaeckers, mitsgaders alle andere, die haer metter penseel, borstel ofte metter venve generen hier ter stede haeren handwerk nyet en sullen mogen exerceren offte doen ten zij dat se eerst burgers ende poorters dezer stede zijn, ende het ghilde ten volle betaelt zullen hebben).It is unclear which groups would from now on belong to the guild as actual members and which would continue to be gildekopers. It is certain that there must have been difficulties with the sellers of different art products, and that this was partially the reason for the regulation.

6 Membership lists have not survived, but we can sometimes partially reconstruct these lists thanks to a few other sources. Obreen, in his above mentioned Archief, published a list with the names of painters who became burghers, taken from the Amsterdam burghers' book(poorterboek) of January 1584 to January 12, 1605. This book contained only the burghers who paid the fee for their citizenship; native burghers (ingeborenporters), and those who married into this status do not appear on the list. Then comes a gap -- the next preserved book listing those who paid a fee to become burghers covers March 9, 1636, to February 3, 1652, while the book of burghers by marriage and native burghers covers November 19, 1648, to February 13, 1655. Painters appearing in these books are summarized by Pieter Scheltema in his work on Rembrandt. In Aemstels Oudheid, the same author published the names of the painters who wereburghers between 1655 and 1700, basing this on the alphabetically ordered burghers' books, which date from February 1655 on. $^{6}$ It has always been a point of interest that in January 1652 a number of painters, many of whom had already been working in Amsterdam for a long time, purchased burghers' rights. From this it has been concluded that these painters had not previously become guild members but were now forced to do so. I would prefer not to endorse this. According to the ordinances of the Guild of Saint Luke and other guilds, guild members were not always burghers, even though this was compulsory. Now and then the municipal authorities followed up on this infraction. In January 1652, the burghers' book covers six and a half pages and probably the following month or months continued in this way, whereas the months before cover only two pages on average. I conclude from this that a check of the guild members had taken place and that the non-burghers among them had been forced to pay the fees for their citizenship. ${ }^{7}$

7 A separate kleinpoorterboek, or vrijcelenboek [a book devoted to burghers with lesser rights] starts on May 13, 1670. While it was not officially permitted, many guilds allowed individuals who had bought only this cheaper certificate to become members. Scheltema did not include these kleinpoortersboeken in his publication.

On two occasions in the seventeenth century, groups separated from the Guild of Saint Luke. In 1662 , the booksellers and bookbinders joined the book printers, who had never been included in the guild system, and two years later the compass makers did the same. Little can be related about the latter, who fell under the Guild of Saint Luke only in theory. To the booksellers, however, I will devote a great deal of attention, since their guild archive has been well preserved and thus serves as a very important source. The booksellers' guild book lists all new members in alphabet- 
ical order, starting with the members of the old Guild of Saint Luke who had transferred to the new booksellers' guild. The members are listed in chronological order following the year of their membership. Some difficulties occurred. Later on, when I attend to the sales, I will elaborate on one specific group, the art- and map-sellers, whose members were permitted to make their own decisions about which guild they preferred to join. ${ }^{8}$

9 Thanks to the fact that the City Orphanage (Burgerweeshuis) was entitled to part of the incoming burghers' fees, we possess a unique document, which lists all the members of the Guild of Saint Luke. As I already mentioned, some guild members avoided the requirement of citizenship because of the costs. In 1688, the regents of the City Orphanage complained about the meager income from the burghers' fees. In response to these complaints, the burgomasters requested that all guilds provide details of the totality of their membership and the reasons for their permissions to join. These reports are preserved in the City Orphanage's archives.

10 This important list of the members of the Guild of Saint Luke follows as Appendix I. One will find that many well-known painters were in arrears, either because they only possessed a certificate (vrijceel) or because they had failed to appear before the guild overseers. The submission of names is unfortunately incomplete; some names appear twice and divisions of craft or entry year as a member, as is the case with other such lists, are missing.

11 Finally, we are allowed two last glimpses into the guild proceedings. In 1696, problems arose between the Guild of Saint Luke and the masons' guild regarding the sculptors [the Guild of Saint Luke argued that the sculptors should join their guild]. To validate their point of view, the overseers produced a list of thirty-seven sculptors who had become members of the Guild of Saint Luke during the course of the seventeenth century. Secondly, in 1700 attempts were made by the fine painters, sculptors, and engravers to separate from the glassmakers and the house painters. Concerning this matter, a petition was signed by thirty-five fine painters, sculptors, and engravers. $^{9}$

12 There is still another possibility for discovering if and when someone became a guild member. This is the so-called funerary medallion (begrafenispenning) that members received upon entrance into the guild. A few of these have been preserved. The most famous is that of Rembrandt, preserved in the Rembrandt House Museum in Amsterdam, about which two notes have been published, so far as I know. W. F. K. Zwiersina described it in 1913 in the publication Architectu$\mathrm{ra}^{10}$ This brass medallion, measuring $28 \mathrm{~mm}$ in diameter -- the guild's oldest form of funerary medal -- shows on one side the arms of the Guild of Saint Luke and above this the year 1634 (fig.1a). The reverse (fig. 1b) bears the name Rembrandt [spelled Rembrant] Harmens with the letter $S$. In 1913, the medallion was still in a private collection. The owner had told the board of the Rembrandt House Museum a few years earlier that she possessed a medallion bearing the name of the master and asked if they were interested in it but received no reply. The board probably believed that they were being offered some commemorative medal. Once Zwiersina had examined the medallion in person, it ended up in the Rembrandt House after all. In 1924, J. F. Backer referred to the medallion as proof of Rembrandt's membership in the guild but incorrectly maintained that 1634 was the year the medallion was struck [in fact, the medallion is engraved] ${ }^{11}$, while Zwiersina had correctly claimed this as Rembrandt's year of membership and the $S$ as 
referring to the profession of painting [schilderen].

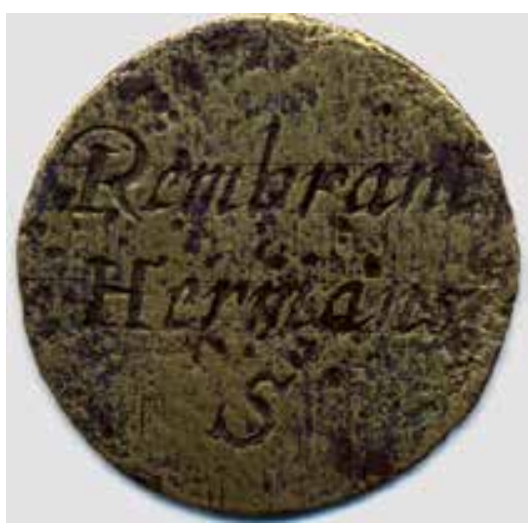

Fig. 1a Guild Funeral Medallion of Rembrandt (recto), 1634, diameter $28 \mathrm{~mm}$. Rembrandt House Museum, Amsterdam.

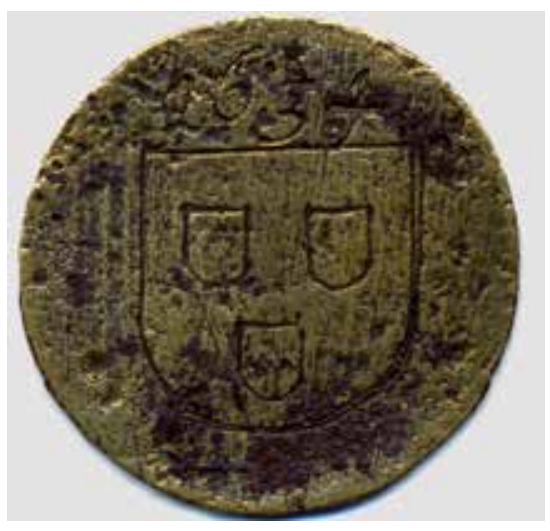

Fig. 1b Guild Funeral Medallion of Rembrandt (verso), 1634, diameter $28 \mathrm{~mm}$. Rembrandt House Museum, Amsterdam.

13 The year 1634 and the letter $S$ had their practical uses. In 1579, it was decided that all guild members must attend the burial of a fellow guild member or his wife. From other guilds, we know that the servant of the guild (gildeknecht) distributed the medallions and that those present subsequently handed them in at the funeral. Those who did not do so had to pay a fine, which increased with time, as did other fines. As the guild grew larger, however, a limitation was introduced. On January 14, 1621, it was ordained that burial would only be conducted in the presence of members of one's own profession or craft. Three early eighteenth-century regulations (keuren), from 1715,1720 , and 1735, teach us about the customs that had gradually been initiated. At first the seven eldest and seven youngest guild brothers had to carry the coffin, then the fourteen who lived nearest the deceased, and finally the fourteen youngest. If only for that, the year on the medallion was needed. Regarding the letter S, I wish to point out that in 1735 the fine- or art painters (fijn- of kunstschilders) appeared reluctant to attend burials of the house painters (kladschilders). ${ }^{12}$ Therefore, the guild announced the abandonment of the rule of distinctions between fine painters, house painters (grofschilders), and gilders (vergulders).

14 Attending burials, in the sense of paying last respects to the deceased, essentially ended up as a financial matter: the collection of fines from the absentees for the benefit of needy guild members [the armenbos or fund for the poor]. Furthermore, since guild members gradually began to consider guild burial less distinguished (deftig), they refrained from attending, an attitude which negatively affected income from fines. In 1695, the guild therefore decided that the family of a deceased member who was buried outside the guild, would pay a fine of 6 guilders. It is not clear whether special arrangements -- similar to those of the booksellers, for instance -- were made by Guild of Saint Luke members wishing to buy off burial attendance duties by paying a fixed yearly amount.

How often was the medallion in the Rembrandt House brought to burials between 1634 and 1669? I dare not guess. I assume, however, that Rembrandt frequently chose to pay the fine. I just want to address here the year in question. In 1634, Rembrandt had already been settled in Am- 
sterdam for two years. He likely became a member only in that year because of his marriage. That happened frequently, possibly in part because the sons of masters enjoyed certain privileges and membership for the father prior to the birth of sons could be a requirement.

16 During the seventeenth century, artists in various other places appear either to have distanced themselves from their city's Guild of Saint Luke or to have secured a certain privileged place within it. This did not happen in Amsterdam. Perhaps the famous artists' festivals of 1653 and 1654 were a step in this direction. ${ }^{13}$ But if so, they were not rewarded with success, nor were the attempts of 1699 and 1700 . Only at the end of the eighteenth century did the purveyors of art succeed in occupying a special position within the guild system.

17 Regarding limitations on the number of pupils, we can be certain that these were either a dead letter for the painters, or were intended not for them but for house painters and glazers. This reminds me, for example, of Sandrart's statement regarding Rembrandt:

As a result, good fortune brought him riches and filled his house in Amsterdam with almost innumerable young people of good family, who came to him for instruction and tuition. Each paid him 100 florins a year. To this we must add the profit which he made out of the pictures and engravings of these pupils, amounting to some 2,000 to 2,500 florins in total -- as well as his earnings from his own work (dannenhero ihme das Glück große baare Mittel zugetheilt und seine Behausung in Amsterdammit fast unzahlbaren fürnehmen Kindern zur Instruction und Lehre erfüllet, deren jeder ihme jährlich in 100. Gulden bezahlt, ohne den Nutzen, welchen er aus dieser seiner Lehrlinge Mahlwerken und Kupferstucken erhalten, der sich auch in die 2000 bis 2500 Gulden baares Gelds belauffen, samt dem, was er durch seine eigneHand-Arbeit erworben). ${ }^{14}$

\section{Overseers and Servant of the Guild}

Since the archives have been tidied up [and therefore lost], we can only trace a few names of guild overseers(overlieden) from the sixteenth and seventeenth centuries. At the time of the guild's separation in 1579, the board consisted of four overseers, of whom two resigned every year. They were the well-known sculptor Joost Janz [Bilhamer], a painter named Willem Tonisz, and two glazers whom I do not need to name. Willem Tonisz was probably a house painter. Of the four overseers mentioned in a document of December 22, 1615, Christoffel Jansz, Jeurriaen Jansz, Cornelis van der Voort, and Frans Willemsz, we recognize the third man as a fine painter. ${ }^{15}$ In 1619 , when the booksellers became more dominant in number, they too were awarded places on the board. At that time, a sixth officer must also have been assigned, because on January 14, 1621, a regulation was issued that every year on Saint Luke's Day -- October 18 -- three new overseers would be chosen. This makes clear that the overseers were in office for two years. So far as can be inferred there were two fine painters among them. On October 3, 1629, the guild overseers, the painters David Colijns and Nicolaes Eliasz [Pickenoy], acted as appraisers [taxateurs] in an official document for notary J. Warnaertsz, while on March 16, 1636, the overseers Dirck Pietersz Wittepaert and Gilles d'Hondecoeter performed this role for notary L. Lamberti. This Dirck Pietersz Wittepaert, better known as Bontepaert, made a declaration as an overseer on May 31, 1631, together with his colleagues Cornelis Symonsz and the painter Ysaack van Coninxloo. ${ }^{16}$ This again indicates that two fine painters functioned as overseers at that time. 
In 1633, the guild assigned the booksellers another overseer on the board, giving the impression that the number of overseers had risen. When in 1662 the two overseers of the booksellers, Daniel Elsevier and Johannes van Ravesteyn, set up a new guild together with their fellow professionals, six unnamed overseers of the Guild of Saint Luke protested, indicating that the overseers numbered eight. In the printed ordinances of a later date, 1789, I can point out three overseers from January 23, 1658: the painter Dirck Santvoort (the son of Wittepaert mentioned above), the bookseller Daniel Elsevier, and the glazer Hendrik de Hont.

20 The number of overseers decreased after the exodus of the booksellers in 1662. In 1688, one finds -- in Appendix I -- five overseers in office. It seems that two fine painters were on the board, namely Jan de Kaersgieter and Pieter Niedeck. Pieter Penninck and Jan Hooy were glazers; Dirck van Voorst was a sculptor.

21 I write all of this in such detail to show how little we really know. The other fine painters who functioned as guild overseers remain unknown. We can nevertheless gather from the information available that the Santvoort family of painters played a role for a long time. After all, outgoing officials frequently were reappointed as soon as possible. ${ }^{17}$

22 Regarding the more unusual tasks of the overseers, I wish to point out here that they served as appraisers only twice. More instances of this might well be traced in the future, but certainly appraisal played a role of minor importance for the overseers. We mostly find painters who were involved in the art trade, or art dealers who were not painters. The references (renvooien [references concerning arbitrary affairs]), on the other end, would certainly have been important. In an undated request from the end of the seventeenth century, the overseers declared that they were so busy with this task -- and it concerned paintings as well -- that they would like to receive a reasonable salary for their efforts. The request was never granted. ${ }^{18}$

23 In some guild archives, such reference books (renvooiboeken) have been preserved, including those of the surgeons. Those books contain not only the actual references or affairs that were passed on to the overseers by the various legal authorities to formulate an expert judgment, but also those cases in which the parties directly turned to the overseers.

24 The loss of the reference books of the Guild of Saint Luke is hugely regrettable. The books could possibly have provided the answer to the famous case regarding Claudius Civilis, which hung for a short time during 1662 in the town hall but was removed for reworking by Rembrandt. [Quite apart from this commission,] the fact that guild overseers could have a say in cases regarding likeness is evident in a document from February 23, 1654 before notary Lock. Rembrandt demanded full payment; only then would he complete a portrait commissioned by Diego d'Andrada, which in d'Andrada's judgment failed to show a good likeness, "and leave it to the judgment of the board of the Guild of Saint Luke whether the painting is a likeness of the girl or not and if they decide that there is no resemblance, he will then change it" (ende stellen t' aen 't oordeel van de Overluijden vant St. Lucasgildt of het de dochter glijck dan niet ende soo sij seggen dat het haer niet ende gelijckt soo sal hij t veranderen).

25 The servants (knechten) of the guild are better documented than their overseers. Abraham Ger- 
ritsz is documented as a servant in the registers of sales -- to be discussed further below -- from January 15, 1628, until February 9, 1638. In later times, the registers of civil servants (ambtenboeken) list the following names: Jan Bastiaansz Toonhuysen 1657, Michiel van der Banck 1670, and Johannes Wijmer 1672, succeeded on January 31, 1701, by Zacharias Vosmeer. In contrast to [the practice at] several other guilds, these servants were, at least during the second half of the seventeenth century, not members.

26 I have nothing to say regarding Abraham Gerritsz. ${ }^{19}$ Jan Toonhuysen was already listed as a servant of the Guild of Saint Luke in his publication of the bans for Margrita Wachtels on October 11,1657 . He was discharged for corruption in $1670 .{ }^{20}$ A year later, on May 14, 1671, he was buried in the Westerkerk. His successor, Michiel van der Banck, served for only one year and was buried in the Oude Kerk on November 4, 1671. His successor Johannes Wijmer was originally a silk merchant (zijreder), then became an agent in 1664 [serving] until his death in $1700 .{ }^{21} \mathrm{He}$ was married to Jacomina van Aelst from the well-known Gelderland paper manufacturing family. His background was probably more impressive than that of most of his overseers -- he was, among other things, a second cousin to the burgomaster Jan Six. The position of servant of the Guild of Saint Luke, which he occupied until his death, must surely have had its advantages.

27 According to seventeenth-century ordinances, the tasks of the servant mostly concerned sales. In 1630, it was established that the servant had to be present at all sales of paintings and would receive twenty-four stuivers per day. Before 1630, however, we also see Abraham Gerritsz as a buyer at auctions. In 1659, the servant's duties were expanded to include sales of paintings, sculptures, books, and art. From now on he would receive two guilders per day, unless the sale lasted for more than six days, in that case only thirtystuivers. For announcing the sale he would also receive thirty stuivers. It was strictly outlined that no one but the servant was permitted to distribute leaflets for the sales (biljetten) or catalogues. But apparently that happened anyway, because on February 4, 1702, this regulation was repeated and the fine set at six guilders. On February 1,1666 , the servant was given the right to fine the instigators of secret sales and lotteries, or the raffling of paintings (rijfelarijen) in inns, as well as to fine the innkeepers or the hosts and sellers.

In 1662, the sale of books obviously ceased. Nonetheless it must have been an advantageous position. Otherwise a person such as Wijmer would not have been attracted to it. Of the infamous eighteenth-century century sinecures, in which the work was done by substitutes, there is no mention yet. I will now offer further explanation concerning those sales that are closely connected with the guild.

\section{Sales in General}

29 The history of the sales goes back to an early date. I owe my story to the printed sources, such as the Rechtsbronnen of Johannes Christiaan Breen and the Handvesten of Herman Noordkerk; to a portfolio with items collected by the latter in the mid-eighteenth century; to the Groot Memoriaal [part of the archive of the burgomasters]; and to the sales registers of the orphanage archives. ${ }^{22}$

30 In an instruction of 1507 to the clerk of the Orphan Chamber (weeskamer), payment for the sales was due within six weeks provided that a surety (borg) was posted, otherwise cash was expected. 
The first announcement of sales by the superintendant (concierge) of the city hall dates from 1544; he was permitted to hold these sales together with the previously mentioned delegate or messenger (bode) of the Orphan Chamber. In time, the superintendant was permitted to hold executive sales [sales of bankrupt estates] only, with the delegate of the Orphan Chamber holding all others. The salary, which they had to share with the official secretaries of the city (secretarissen), amounted to 5 percent. If the sellers did the collecting themselves, it was possible that they only paid 1 percent. A separate auctioneer oversaw the sale of ships. In 1632, this was a certain Jacques de Vos. He obtained the right to auction all commodities (koopmanschappen) for a payment of 1 percent, of which one-third went to the official secretaries, one-third to the agents (makelaars), if they were involved in the sale, and one-third or two thirds, respectively, to De Vos. Apparently this decision was indeed taken as agents started conducting the auctions themselves; at any rate, they were strictly forbidden to conduct sales. Jacques de Vos had already died in 1633, but his widow and son continued the activity and even tried to increase their involvement in it. In 1640, they were forbidden to involve themselves in the sales of the East and West India Companies. At these sales, the messengers of the Orphan Chamber served as auctioneers for these companies.

31 In the course of time, the De Vos family had other auctioneers of commodities work alongside them, and because the first of [these individuals] settled in the paalhuisje on the Nieuwe Brug [New Bridge] they got the name auctioneers of the Nieuwe Brug [afslagers van de Nieuwe Brug], although the sales were actually held throughout the city. Quite understandably, problems arose with the other auctioneers over defining the term "commodities." On April 19, 1658, it was decided that the auctioneers of the Nieuwe Brug should be the ones to do the sales of all items from trade coming primarily from sea voyages, which were being voluntarily sold wholesale by English or Dutch auction [op- of afslag, two different methods of auctioning], while the auctioneers of the Orphan Chamber were to sell all other articles, shop items, tools, and goods connected with estate- and death-inventory sales that were sold voluntarily. On July 30, a further explanation was given: the goods from sea transport must still be in the hands of merchants (in de eerste hand). Theproblems only disappeared when on December 20, 1658, it was decided that apart from a few previous remunerations everything would go into one deposit which would then be divided head for head with the auctioneers of the Nieuwe Brug -- then five but later three in number -- and the four auctioneers of the Orphan Chamber.

32 The sales by the auctioneers of the Nieuwe Brug were never of any consequence for the art world, but the two other types were consequential indeed. These will therefore be examined in detail.

\section{Executorive Sales}

33 Executive sales [of bankrupt estates] were carried out, as we saw, by the superintendant (concierge) of the town hall. In consecutive order, these were Jacob Huych Tomasz, appointed in 1587, and his son Thomas Jacobsz Haringh, appointed after the death of his father in 1617. Thomas remained in his post until his death in 1660, thus for forty-three years, but already on January 6 , 1660, the notary Frans Uyttenbogaert was placed at his side "as an honest and competent person to overlook the superintendant's work" (als eerlijck ende bequaem persoon om de concerges ambt waer te nemen). He was succeeded in 1686 by Mr. Johan Uyttenbogaert. In turn, he was succeeded in 1690 by Jan Wijnkoop, who saw the century out. 
34 For us, the most important of them is Thomas Jacobsz Haringh. From his father's marriage dowry upon his remarriage in 1603, it appears he was born in 1586 or 1587. His father, Jacob Huych Thomasz, was the son of Thomas Huych or Haringh and the grandson of the well-known Amsterdam burgomaster Jacob Haringh Pietersz. Thomas married Cornelia Stricke of Utrecht in 1616 and made his entrance the following year as superintendant of the town hall. His period in office was not always accompanied by good fortune. He was in arrears of large sums with regard to executed goods sold by him: in 1650, 34.000 guilders, in 1653, 54.400 guilders, while in 1617 he had had to put up only 6.000 guilders of sureties. After his death, the treasurers signed a deed with his children whereby the city received four houses that had belonged to the deceased, thereby cancelling out any other debts. Among those houses was his heavily mortgaged estate at the Donkere Brug near Baambrugge, which was bought for around 11.000 guilders by Lucas Occo. ${ }^{23}$

A portrait of Thomas Haringh is preserved in the De Moor family album (fig. 2) ${ }^{24}$ Illustrate it here along side the famous etching by Rembrandt (fig. 2), who in 1655 immortalized him. The relationship with Rembrandt resulted not so much from the auctioneer's profession, as from the fact that father and son were collectors of works on paper, among other things. This is apparent from the two wills of the elder Haringh, dated May 16, 1652, and March 28, 1653, by the notary J. van de Ven.

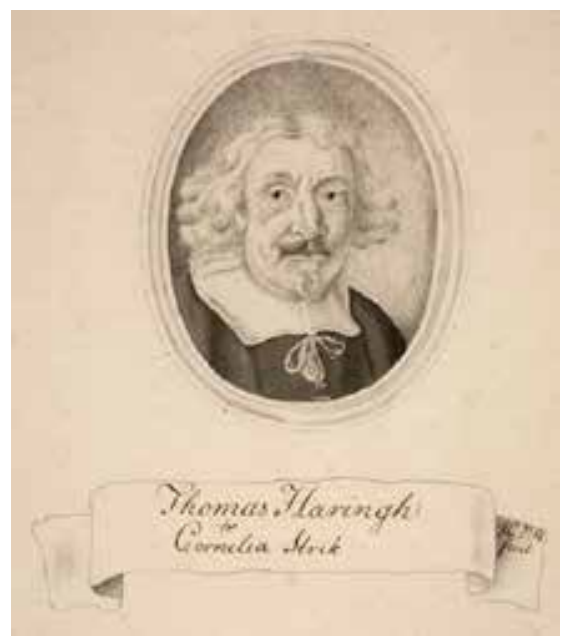

Fig. 2 J. C. van Royen (after an unknown portrait), Portrait of Thomas Haringh, from the De Moor Family Album (Legaat van Beresteyn). Ikonographisch Bureau, Rijksbureau voor Kunsthistorische Documentatie The Hague, inv. no. 203166 (Photo: Collection Rijksbureau voor Kunsthistorische Documentatie, The Hague).

Almost nothing remains of the administration of Haringh's executive sales. Noordkerk [in 1748] could still take extracts from the books at the town hall, including, for example, "from the book of executive sales of furniture goods beginning 27 February 1618 and ending 27 April 1619" (uyt 't boek van executiën van meubele goederen beginnende 27 february 1618 en eyndigende 27 april 1619) concerning the sold goods from the [estate of] lantern maker Jacob Cornelisz. These registers were disposed of later on. Fortunately, another source can provide us with the data for certain sales, and that is the archive of the Bankruptcy Chamber (Desolate Boedelskamer). In their journal one can find the receipts that the superintendant recorded every two to four months and thereby the summary of sales with date, name of owner, amount, and sometimes also a description of what was sold.

I will obviously take Rembrandt as an example. Based on the authorizations to sell, and dates of payments noted down in the Bankruptcy Chamber's main book, the sales have until now been 
only vaguely dated, and rather incorrectly as it appears now from the Bankruptcy Chamber's journal. ${ }^{25}$ In the relevant journal, one can find, in the account of November 1, 1656, the first sale at the lower end of the entries, thus certainly held in September of that year, and with a revenue of |1322:15:--. On March 21, 1658, there follows the account regarding the, now luckily-dated, goods that were sold [vercofte goederen] on November 21, 1657, for '2516:10:--. On July 26, 1658, two sales were accounted for: one of goods sold on April 18 for 1432 : 5:-- (according to the authorization of February 14 these were furniture and house contents) and one of a few paintings sold on July 5 for $95: 15:--$. Certainly the last was a small auction, which coincided with two other sales of paintings. Then finally on February 14, 1659, three sales were accounted for: paintings on October 29, 1658, for $\mid 126: 10:--$ and sold goods on December 20, 1658, in one case for $180:--:-$ and another for ¡390: 9:--. The sale of October 29 took place as a follow up to two other sales of paintings and one of prints on October 28.

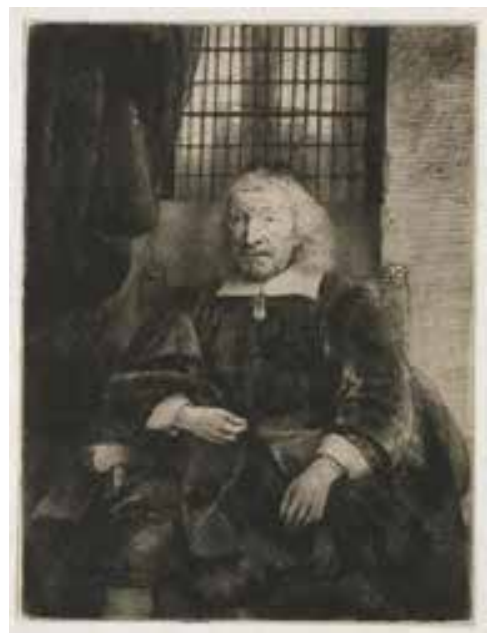

Fig. 3 Rembrandt, Thomas Haringh ("The Old Haringh"), ca. 1655, drypoint and burin, $195 \times 150 \mathrm{~mm}$. (B.274)

The December sales must have concerned art on paper. For on September 24,1658 , the commissioners instructed Adriaen Hendricxen to attend this sale of works on paper, and beforehand to "sort and distribute in the most competent way the aforementioned inventory as he thinks sensible" (op de bequaemste maniere te sorteren ende verdelen, soo hij ten meesten besten van den voorschreven boedel geraaden vinden sal). This Adriaen was certainly the same as the sixty-threeyear-old Adriaen Hendricksz de Wees who, together with Lodewijck van Ludick, on March 19, 1659, made a statement before notary Listingh that the "paper arts, rarities, antiquities, medals and marine plants" (papieren konsten, rariteyten, antiquiteyten, medalien ende seegewassen) which Rembrandt owned around 1640 to 1650 were worth up to 11.000 guilders. Evaluating the paintings, which Ludick valued at 6400 guilders, was beyond De Wees's field of competence. As a reason for his expertise, Adriaen indicated his intimate familiarity with Rembrandt and his art and curiosities collection and indicated, too, that he was a great admirer (liefhebber) and connoisseur of such collections and had had many dealings with them.

This Adriaen Hendricksz de Wees, originally a shoemaker, still lived in Beverwijk at the time of his marriage with Hillegont Goverts and stayed there initially. ${ }^{26}$ On October 1, 1639, he was registered as an agent. He died on April 4, 1679, still in this profession. He must therefore have been one of the first art agents. Perhaps some of the stories regarding Rembrandt and the much younger Jan Pieters Zomer, ${ }^{27}$ who only became an agent in 1690, can be traced back to this Adriaen. 
According to the burial certificate of his wife, Adriaen lived in the "Herenlogement" on January 15,1656 . In 1657, at the time of the marriage of his daughter to the engraver Jan de Visscher, his place of residence was given as: "on the Heilige Wegspoort." Finally, Adriaen rented a little house on the Oudemanshuispoort and from there he was buried in the Oude Kerk on April 7, 1674. ${ }^{28}$

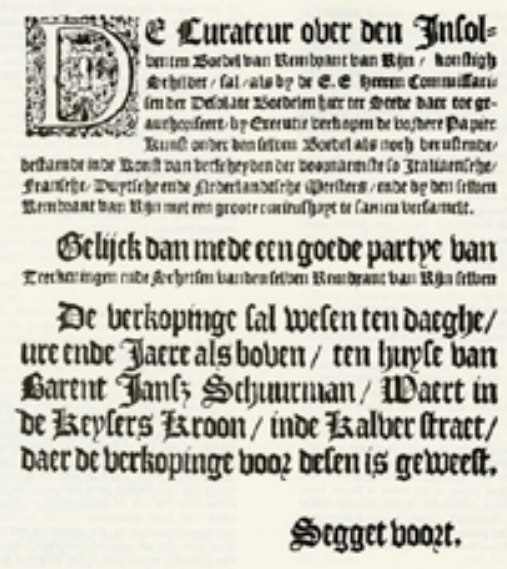

Fig. 4 Handbill for the Auction of Rembrandt's Graphic Art Collection, December 20, 1658. British Museum, London.

40 The sale of works on paper had a remarkably low profit, as far as we can now judge. I will deal with the possible causes of this at a later stage. I just wish to refer here to the leaflet (biljet [or handbill]) for this sale [of Rembrandt's graphic works], which was rediscovered in 1920 in the British Museum (fig. 4). The leaflet was already known at the beginning of the nineteenth century, but in 1906, with the publication of C. Hofstede de Groot's Die Urkunden über Rembrandt, it was nowhere to be found. The date is lacking, but from the data mentioned above we can conclude that it must have announced the sale of Friday, December 20. 1658.

A lost leaflet of sale from the archive of the Bankruptcy Chamber is dealt with elsewhere. ${ }^{29}$

\section{Sales by Delegates of the Orphan Chamber}

42 I will start with the names of the various delegates (boden). Pieter Zegersz, father of the painter Lastman, was an assistant since 1576 and a delegate as of May 30, 1576. Pieter Zegersz was replaced by Pieter Jansz Codde on June 10, 1578, because he remained Roman Catholic. Gerrit Jansz Block replaced the deceased Pieter on June 3, 1597. He stayed in that position until June 1603 but was dismissed due to financial difficulties. Nine years later, in any case, it was noted beside his license of surety (akte van borgstelling) of 1200 guilders, that the amount had been fully paid off to the treasuries. His successor in June 1603 was Gerrit Jacobsz Haring. As appears from an increase of his surety he was still in that position in 1637, but in 1639 -- presumably on January 1 as appears from the burial registers of the Orphan Chamber -- his son Pieter succeeded him. Pieter functioned in that position until the end of 1681 and was subsequently succeeded by his son Jacob. With Jacob's death, in 1727, this line of succession came to an end.

In 1617, Gerrit Jacobsz Haring was joined by another auctioneer, Jan Dircksz van Beuningen, who was succeeded in 1627 by his son Daniel Jansz van Beuningen. In 1646, Mr. Hartman Hartmansz, a surgeon in Rembrandt's first Anatomical Lesson, was established in this post, resigning in 1657 to become auctioneer of the Nieuwe Brug. He was succeeded by the delegate of the city Marten 
Pietersz Schriek, who remained in that position until 1664. His successor, Hendrick van Heyst, died in 1678 and was succeeded by Evert van Tongerlo.

44 In 1636, a third auctioneer was installed, Abraham Jansz (Croonenburgh). At an unknown date his brother-in-law, Jan Joosten van Veen, succeeded him. After the latter's passing, Gijsbert van Sweers functioned from 1648 until 1655, when, due to his bankruptcy, Jan de Blocq replaced him. ${ }^{30}$ On August 29, 1662, the function was taken over by Henricus Westfrisius, but already before 1667 Jan de Blocq returned. After his death in 1680 he was succeeded by Jan van de Putt Jr. Maurits van Cosen, the first delegate of the Orphan Chamber -- a new office -- did not take part in the actual auctioning, as appears from his instruction of January 28, 1640. On August 12, 1656, he was succeeded by Dirck Steenoven, who did serve as auctioneer.

45 This is the full account of auctioneers from the seventeenth century. No doubt remarkable things would have come to light if I had traced the lives of these persons -- all businessmen -- individually, but this was not possible. I will therefore limit myself to the Haringh family, who over the course of almost a century and a quarter produced three generations of auctioneers: first one member of the family alone, who was joined by another in 1617, then in 1636 by two more, and in 1656 by three others.

46 Gerrit Jacobsz Haringh's father was a namesake and full cousin of Jacob Huych (Haringh), the superintendantmentioned above. Gerrit possibly owed his position to this connection. In 1601, at the age of twenty-seven and then just a sailor, he married Lysbeth Pieters. Although his predecessors had all provided surety, he did so only fourteen years after his appointment, together with the new auctioneer Jan Dircksz van Beuningen. When the surety was raised from 10.000 to 15.000 ,Gerrit supplied it on January 9, 1637, with 5000 guilders. He was buried on August 3, 1649, in the Nieuwe Kerk, as was his widow Lysbeth Pieters, on September 20, 1651. At that point they lived on the Rokin near the Lange Brug.

47 Pieter Haringh was baptized on September 3, 1609 in the Nieuwe Kerk. He married Lysbeth Jans Delft in 1641. In 1647, he became the owner of a house, op het Water [Damrak], near the Papenbrug. He functioned for more than forty years. In 1679, his wife died and in 1685 he followed her to the grave. His youngest son, Jacob, was baptized in the Nieuwe Kerk on November 6, 1650. Jacob presumably succeeded his father as an auctioneer at the beginning of 1682. Soon thereafter, he married a girl from the neighborhood, Barbara Elsevier, daughter of the well-known bookseller Daniel Elsevier. About the failure of this marriage one could write a novel. It is sufficient here, however, to state that Jacob Haringh, in his last will, before the notary Tzeeuwen on February 12, 1712, named Johanna de Veer to be his sole heir. She was the divorced wife of Anthony Walraven. Haringh decreed that after her passing everything would be deposited to the Orphan Chamber on behalf of her children. He died in 1727, she in 1748. And so it happened that we still have various documents from the Haringh family in the archives of the Orphan Chamber, some from the seventeenth century, but unfortunately nothing on the sales. ${ }^{31}$

48 I can state the following about the function of auctioneer. We know Gerrit Jacobsz Haringh from the registers of sales by him preserved from 1605 until 1628, about which I will tell more later on. We find him as auctioneer, but also as a buyer of art, among other things. The guideline that 
the auctioneers were not supposed to buy at auction themselves apparently remained a dead letter throughout. These sales mostly took place in front of or in the houses of private individuals, though sometimes in taverns, too, or in front of the auctioneer's own house.

The old condition that buyers who put down a good surety could pay within six weeks remained intact. Yet the auctioneers apparently also gave longer credits, or credit without a good bail, for instance to secondhand dealers (uitdraagsters). ${ }^{32}$ The auctioneers had to transfer the money, which the secondhand dealers had cashed to the sellers, but were allowed to keep a 5 percent salary, half of which was for the city's secretaries, the other half for themselves. Nonetheless, the damages they suffered in cases of financial default had to be covered from their own accounts. And these damages could come to considerable amounts. Such a case occurred in 1625, partly because of the bankruptcy of a secondhand dealer known as the Green Knight (De Groene Ridder). The auctioneers Haringh and Van Beuningen then tried to make the secretaries share the damage. The secretaries of course resisted, stating that the auctioneers should have provided reliable sureties. On March 25, 1625, the arbiters (goede mannen [good men]) decided on the verdict: Haringh got a discount of 200 guilders on the amount owed by him, with the admonition to be more careful from now on, while Van Beuningen had to pay the full costs, since two years earlier he had been forgiven 212 guilders in a comparable case. Similar situations nevertheless kept occurring. In 1642, troubles arose for the son of Van Beuningen, which were even brought to the Court of Holland by the secretaries. On August 30, 1645, another settlement was reached, in which again the auctioneer got a huge discount, together with the order to adhere more closely to the ordinances. The next year someone else replaced him. That the risk was not always due to financial default from buyers who bought according to the terms of a six-week delay of payment (swijch van zes weken) appears in a document by the notary Jacobus Westfrisius, dated June 7, 1718. Michel le Fort -- art trader, innkeeper, and agent for awhile -- declared that he had received 550 guilders from Gerrit Jacobsz Haringh, for whom he had delivered paintings at the house of the hosier Anthoni de Mel on Dam Square, to sell as quickly as possible. The painter Abraham Decker vouched in case of a possible hindrance to the sale. As appears from a document of the following day, Decker, too, had a legal claim on Le Fort and the rights to a part of the sale's profit. We learn two pieces of information from it: the sellers were able to choose the auctioneers they would hire, and the auctioneers even provided monetary advances.

As we have seen earlier in cases where the sellers rather than the auctioneers cashed the money, the salary could be lowered from 5 percent to 1 percent. In fact this only occurred with commodities. In situations like these, certain conditions were stipulated. One can find examples of this at commodity sales of grocers on February 25, 1625, by Van Beuningen and on August 8, 1625, by Haringh. Understandably others, too, strived for such a settlement.

51 In April 1639, a famous art sale took place: the estate of the merchant Lucas van Uffelen was auctioned. We are informed about it by the painter Joachim von Sandrart, who, on April 9, bid on a painting by Raphael up to 3400 guilders, but saw it sold to the merchant Alphonso Lopez for 3500 guilders. Rembrandt, too, was present at the sale and drew the painting under discussion there, apparently the most expensive lot to be sold (fig. 5). To him we owe our knowledge that the whole shipment (cargazoen) brought in nearly 60.000 guilders. It has often been assumed that this concerned a shipload of paintings, since the word cargazoen normally meant a shipment of goods. 
However, if that were the case, the widow De Vos would have appeared as auctioneer, and we will soon see that the sale was done by Pieter Haringh. In fact, the word cargazoen was then synonymous with estates (boedels). ${ }^{33}$ This must have been the case here as well, presumably because the heirs collected the money themselves and paid the auctioneer only 1 percent. Partially on behalf of the other auctioneers -- who had put everything in a big pool (pot), -- problems arose between Pieter Haringh and the secretaries. In accordance with article 30 of the 1627 instruction, Pieter Haringh wanted the 1 percent to be divided between the auctioneers and the secretaries head for head, while the latter retained the usual division of two halves, which was more profitable for them. On August 6, the dispute was settled in favor of the secretaries. Most important for us, the dispute appears to tell us that Pieter Haringh -- the youngest of the auctioneers in both age and function -- conducted this sale. I am assuming that he, born and raised in the field as the successor of his father, received the most important sales.

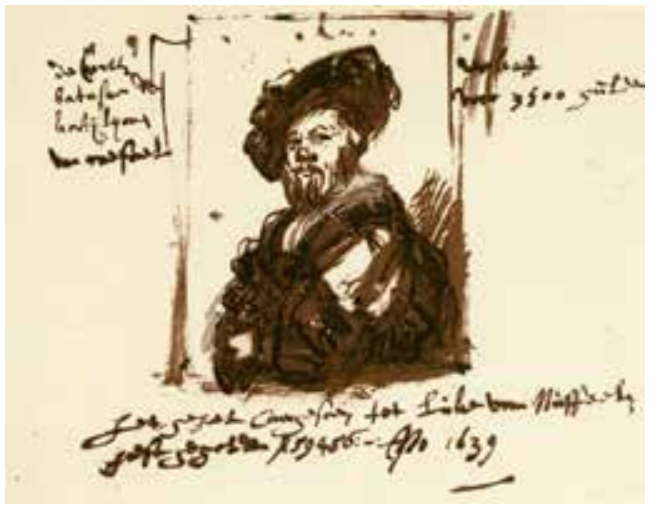

Fig. 5 Rembrandt, Sketch of Raphael's Portrait of Baldassare Castiglione (recording its sale from Lucas van Uffelen's collection, April 9, 1639), 1639, pen and brush in brown, white body color, $163 \times 207 \mathrm{~mm}$. Graphische Sammlung Albertina, Vienna, inv. no.8859.

The 1 percent issue came into play in a different way again in 1657. Catharina d'Overdage, widow of the famous art dealer Johannes de Renialme, asked to pay the salary of 1 percent, too, for the sale on September 4 of her late husband's commodities, which consisted of diamonds, antiquities, and about six hundred paintings, given that she herself would guarantee the debts: the paintings and so forth were after all no decoration, her house was a warehouse.

54 As examples of the trade in paintings, for which this regulation was granted, she conducted the sales of Jacomo Borchgraeff, the heirs Van Uffelen, Thomas Kresser, and others. The secretaries threatened to prevent the sale, if she did not agree upon 5 percent. The burgomasters finally sided with the secretaries, and burgomaster Huydecoper personally noted down that 5 percent should be paid. Herman Noordkerk was still infuriated about it a century later and judged it a very unjust decision.

About the sales of Borchgraeff -- married to a Van Uffelen -- and Kresser I cannot say anything more specific. Somewhat more is known about another big art sale. One will remember that on February 23, 1654, Rembrandt was summoned to finish a portrait for Diego d'Andrada. Rembrandt then ended his answer with the following words: "And if then the accuser is not satisfied with the result, so will he finish the painting as he likes and sell it when he holds a sale of his paintings" (Ende bij aldien den insinuant daermede niet tevreeden is soo sal hij tselve schilderij bij gelegentheijt opmaecken ende als hij vendu hout van sijn schilderij[en] tselve alsdan mede sal vercoopen). 
56 As we shall see later, it was common that artists held sales or vendues once in awhile. About one of these sales by Rembrandt we are somewhat better informed. I published an article about it in the Maandblad Amstelodamum of August-September 1969. ${ }^{34}$

57 On Saturday, December 25, 1655, the first sale took place and six more were to follow, presumably from December 27 until January 1, 1656. Who was the auctioneer at this important sale? We can choose between the just-appointed De Blocq, the surgeon Hartmans, and Haringh. Understand that my thoughts go to the latter.

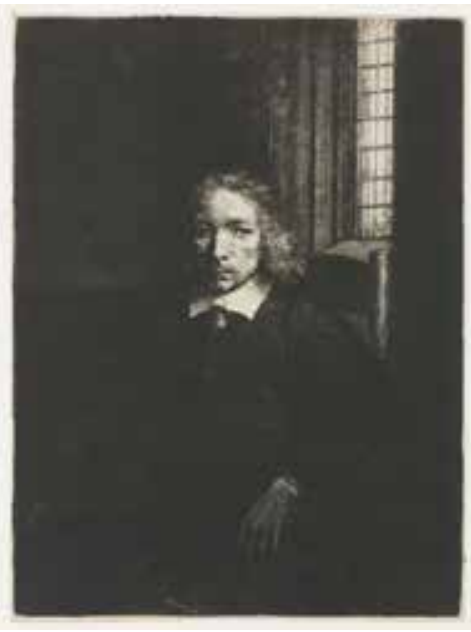

Fig. 6 Rembrandt, Pieter Haringh ("The Young

Haringh'), 1655, drypoint and burin, $195 \mathrm{x}$

$146 \mathrm{~mm} .($ B. 275)

The etching of The Young Haringh which I reproduce here (fig. 6) dates from 1655, and I can not help but wonder if the names of the two etchings The Old Haringh and The Young Haringh might not refer to the two auctioneers (see also fig. 3). Are we dealing with the portrait of the thirty-fiveyear old unmarried Utrecht lawyer, or that of his far cousin, the forty-five-year old auctioneer, and father of several children? Age, demeanor (persoon), and physical similarity to the other portrait seem to indicate the lawyer, but at least I have to point to the possibility that the young auctioneer is depicted here, for one should not forget that already in the eighteenth century the prints were referred to as the old and the young auctioneer. ${ }^{35}$

59 We do not know who benefitted from the sale. In any case, the money did not bring relief, for Rembrandt's estate was due to the Bankruptcy Chamber. The inventory that was made on that occasion surely gives just a limited impression of the extent of his estate. ${ }^{36}$

60 Finally I can name one other huge sale of prints in the Keizerskroon, namely that of Marten Kretzer, on December 1670, known from an advertisement in the newspaper. ${ }^{37}$

61 I return to Pieter Haringh. Just like other auctioneers he belonged to the ranks of merchants and he engaged in other business, as well. In the protocol of notary Jan de Vos, we find him mentioned on January 25, 1651, as the surety for a secondhand dealer (uitdraagster) (thus as an auctioneer). Surprisingly, on May 3, 1651, he appears in a document as a soap-boiler. 
In 1674, the four auctioneers Haringh, De Blocq, Steenoven, and Van Heyst rented a house on the Deventer Houtmarkt in Amsterdam from Jan Otto van Waert for 250 guilders per year, for eight years, starting from November 1. Every Friday, and with a possible continuation on Saturday, they held estate sales there, which until then had taken place in front of their own houses. The costs were covered by a levy of 5 stuivers on 100 guilders, or 0.25 percent of the revenues and further by money paid for the reservation of seats at the table and the benches surrounding it. All four auctioneers had to attend the sales a week after they had been off-duty at the Orphan Chamber. On other days during the week there would be opportunities to sell paintings, commodities, books etc. for a remuneration of 2 silver ducats per day. The days when the goods were brought in and shown would be remunerated with 1 silver ducat. Profits or losses would be divided among the four auctioneers. The original contract with signatures still exists in the portfolio of Herman Noordkerk. ${ }^{38}$

63 How long this auction house, which no doubt rivaled the taverns, existed remains unclear. On December 5, 1681, Pieter Haringh held an auction of jewels, which were found ownerless at the Orphan Chamber. Soon thereafter his son Jacob succeeded him. One might ask whether the auctions were still handled by the auctioneers in person. The answer is yes. When on March 12,1687 , a situation occurred around the all-too-quick purchase at a Dutch auction (mijnen bij afslag) -- an English auction (opbod) had first taken place -- of Commelin's Geschiedenis van Amsterdam, Haringh recommenced the auctioning of the book. ${ }^{39}$ In the index on the notarial protocols of the first ten years of the eighteenth century, one finds a number of documents regarding Haringh and the other auctioneers.

64 I will now proceed to the already-mentioned registers of sales in the archives of the Orphan Chamber. The volumes of Gerrit Jansz Block cover the periods September 9, 1597 -February 6, 1599, and March 31, 1600 -June 21, 1603. So far as can be traced all the sales here are summed up randomly. Then there are the registers of Gerrit Jansz Haringh from July 16, 1605 -January 28, 1615, from July 6, 1616 -November 7, 1617, and from March 23, 1620 -December 13, 1628. During this period there were two series, namely one of estate sales (erfhuizen), whether or not they resided under the Orphan Chamber, and one of the voluntary sales (willige verkopingen). The above-mentioned registers supply only the estate sales. Only one volume of voluntary sales is preserved, from July 22, 1608 -June 3, 1610. It covers exactly the same period as in the register of estate sales. Five volumes of estate sales conducted by Jan Dirckz van Beuningen are preserved, from August 10, 1617 - January 4, 1623, and from December 2, 1624 -July 4, 1626. The last volume, from April 8, 1626 - September 22, 1626, concerns voluntary sales, so far as can be traced. From the son, Daniel Jansz van Beuningen, three volumes of estate sales are known, from March 6, 1627 -March 13, 1630, June 8, 1635 - August 18, 1636, and January 28, 1637 - April 14, 1638. From the auctioneers Abraham Jansz and Mr. Hartman Hartmans two volumes are preserved; they list a summary of every sale, the total yield, and the payment from the estate sales regarding their whole term of office, respectively June 25, 1636 - September 19, 1643, and March 24, 1646 June 12, 1657.

65 As remarkable posts, I list from the last volume the sales of the estates of Elias Herckmans on September 23, 1648, with a yield of $f$ 661:13:--; the paintings from the inventory of Anthoni Claesz on December 21, 1649, yielding $f$ 629:13:--, both on Dam Square; and paintings from Samuel 
Adriaensz (a cooper on the Deventer Houtmarkt, who was buried in the Nieuwezijds Kapel on September 29, 1655) on April 11, 1656, yielding $f$ 2000: 5:--, in the Herenlogement. A higher yield was brought by the sale of Jacob Jorisz's estate on the Kalverstraat on April 17, 1654, namely more than 13.000:--. Jacob Jorisz was buried in the Zuiderkerk on March 24, 1654. The sale of the estate of Barbara de la Vigne on September 18, 1647, on the Bracke Gront raised almost 16.000 guilders.

66 The registers with precise records of the sales are obviously of greater importance. They have often been used, mostly by art historians, but always haphazardly. In a note, I will therefore concisely list the sales that concerned art alone and several other sales in which important artifacts were sold together with other goods. ${ }^{40}$

67 From a relatively early date onward, the paintings are indicated not only by their subject but also with numbers or sometimes with letters; however, the registers are never in the right sequence nor are they complete.

68 I would like to point out some more peculiarities. Among the buyers on January 15, 1628, one finds Abraham Gerritsz, the servant of the Guild of Saint Luke, alongside Haringh. As we already saw, he was at that moment not yet officially in office. But he was indeed officially present on July 10, 1635, and March 9, 1637, when he bought a "kitchen piece" (kocken) and a share of prints (deel printen). Likewise, the storer (oplegger) of the goods bought from time to time as well. On August 28, 1612, the storer was a certain IJsbrant. On February 9, 1638, it was Thomas Pietersz, who, at the publication of his bans on October 4, 1626, was said to deal in paintings. This was a violation of the rights of the sworn appraisers (gezworen schatsters) and in 1647 their rights were officially restored. ${ }^{41}$

69 Not all of the buyers' names were made public. Often the documents read "at the request of" (op wiens versoeck). The names of buyers who paid cash were, especially in later times, no longer noted. However, most of the buyers put forward sureties. This finally brings me to another point in need of correction. Often an address is mentioned. From this it has been concluded -- and rightly so in my opinion -- that the address concerned persons not known to the auctioneers. Sometimes no address is mentioned, only the name of a person preceded by "or," "at," or "with" (of,tot, or bij). In the last two cases, it was always assumed that the buyer lived at the house of that person. From a sale of October 2, 1608, it follows that this is not always the case. The merchant Hans van Loon, who bought a painting there, is indicated as "with Jacob van Neck" (bij Jacob van Neck). In 1606, Van Loon lived in the "Raap" at the Zeedijk and Van Neck at the Oude Vesten between the Korsjespoort and Jan Rodenpoort; it is of course possible that one of them had moved. But one should consider the possibility of securities (borgstellening).

70 At the sale of February 22, 1635, Rembrandt bought for the first time, so far as can be deduced from the registers that have been preserved. On this occasion "Rembrandt van Rijn at Uylenburg" (Rembrandt van Rijn tot Uylenburg) is noted. From this it has been assumed that Rembrandt continued to live with Saskia's cousin after his marriage. That is highly possible, but it cannot be accepted with absolute certainty. 
71 Lastly I will discuss the expenses of the sales. I give as an example the sale of the estate of Cornelis Pietersz and his wife in the Sint Jacobskapelsteeg in front of the Witte Lam, on January 28, 1603. The profit was $f$ 1095: 8:12. However, deducted from this was $f$ 54:15: 8 as salary for the auctioneer, 4 stuivers for announcing the sale (hetomroepen), 10 guilders for storage, $f$ 1:10:--for three days table, $f$ 2: 5:--for the extract, and 5 stuivers for the weighing of silver and gold, so in total $f$ 68:19: 8. The announcing of small sales was usually cost only 2 stuivers. There is no mention of printed leaflets for the sale. In due course these expenses were no longer settled via the auctioneers and so they disappeared from the registers.

72 Conditions are mentioned at some sales, since they deviated in the case of sureties from the usual cash payment due in six weeks. I already mentioned the sales of groceries and can add the sales of wood, for instance, from December 15, 1617. However, I would like to focus more extensively on the sales of books, which were covered by the Guild of Saint Luke as well. At sales from and among booksellers the quantities were often huge, and books could only be resold slowly, in contrast to other merchandise. From this situation the concept of payment in terms developed, as evidenced by the sales noted in these registers. ${ }^{42}$

73 A sale of the books of Barent Adriaensz [Hartoghsvelt], bookseller, is the first example of conditions regarding payment in terms. I include these conditions in Appendix II. The sale of March 12 , 1613, raised $f$ 3945:18:-- and the salary amounted to the usual 5 percent. More sales of books in larger quantities followed. But only at the March 15, 1638, sale of the estate of Michiel Colijn do we find these conditions again (see Appendix). This time the salary did not amount to the usual 5 percent anymore, but 144 guilders on a profit of $f$ 7,187: 9:-- in total, thus 2 percent; since due to the terms the seller actually received considerably less than the real yield. It was the beginning of the strange habit of payment in terms, which would go on to play an important role in the book trade. As for the auctioneer, he did not necessarily take this for granted. In 1699, the salary was established at 2.5 percent, but in the eighteenth century problems arose yet again. ${ }^{43}$

74 At these book sales sureties are often mentioned in the registers. I assume that these were not put forward on behalf of the auctioneer, but on behalf of the payment in terms. On April 26, 1627, one finds Wouter van Kermt, tailor in the Spaarpotsteeg, as a surety for Jacob Elsevier, bookseller in The Hague. Over and over at the above-mentioned sale of the estate of Michiel Colijn one finds the bookseller Hendrick Lourisz ${ }^{44}$ noted as a surety; he was also a surety for, among others, Louis Elsevier. At the sale of the library of Minister Pulleus on December 4, 1629, Menasseh Ben Israel is listed among the buyers. In one instance, there is a note behind his name that reads: or Hendrick Lourisz.

\section{The Guild of Saint Luke and the Sales}

75 Other guilds sometimes assured sales for themselves. At Arent van Liesvelt's sale of hoops and wine gauger tools on January 3, 1625, the Van Beuningen register mentions that a servant of the coopers' guild held the sale, that he will collect the badges, and that any possible debts or damages will be levied against him, so that no salary is charged. On October 5, 1664, the overseers and servant of the smiths' guild declared that it was an old custom for the servant to auction the shop and tools after the death of a guild member. This way the benefit was much better than had the sale been conducted by an auctioneer, since the secondhand dealers did not take a share. On 
November 21, 1664, the complaints of the auctioneers were granted. The cloth dressers were more successful. On April 19, 1658, they were allowed to hold sales of clean cloth-dressing equipment by the guild's servant, with the city's delegate (bode) attending. ${ }^{45}$

76 Although it was therefore not impossible in these times for a guild to gain influence over direct affairs concerning sales, the Guild of Saint Luke never got so far. The overseers, or at least the painters among them, probably realized with a certain distress that the art trade was rapidly increasing. If the secondhand dealers once actually drove this art trade, their share now gradually diminished. The demand for paintings was huge. And as a result, many copies were produced and all sorts of shady businesses came into vogue. ${ }^{46}$ At the beginning of the seventeenth century, it became customary for Antwerp citizens, whose city was a center of the art trade, to buy paintings at the Friday market, among them lots of copies, and bring them to Amsterdam in order to hold sales. No ordinances concerning these sales existed, but now the guild's overseers asked to put an end to such activities, thus prohibiting sales by strangers. The judges did not go that far, but they did decree on November 10, 1608, that strangers from now on could only sell, or allow sales, with permission from the burgomasters. If they did not seek permission, the overseers were allowed to prevent the sale. The request of the overseers, included in the regulation, provides an excellent insight into these violations. This time, however, we know about the sales themselves from the only surviving register of voluntary sales by Haringh. On September 30, 1608, paintings were sold in the Nes at the request of Juffrouw Johanna Artsen from Antwerp and Jacques van de Lamen. Among the buyers we find several Amsterdam art clients -- including the painter Garbrant Ariansz (none other than the famous Gerbrand Bredero, who had not yet begun writing poetry and was still painting). He bought two paintings from Van der Lamen, together for $f$ 22: 5:--. The profit from the sale amounted to $f$ 1006:--: 1 . Shortly afterward, two other sales followed. On October 2, 1608, the paintings from Felix van Lun (?) produced $f$ 1118:15:-- and on October 29, 1608 , those by Valerius van der Houven produced $f$ 305:12:--.

77 Valerius was an Amsterdam resident; I cannot say anything about Felix. However, Juffrouw Artsen, who was herself present at the settlement, and the painter Van der Lamen were both from Antwerp. [Although he was from the Southern Netherlands,] Van der Lamen operated in Amsterdam. Sometimes he was present there, sometimes in Amsterdam. On April 7, 1623, he testified that two years earlier he had stood surety over the sale of twenty-four devotional works by Guilliaume Wittenbroot of Antwerp to Jacob van Nieulandt. ${ }^{47}$ Then there is the escalating argument about an executorive sale, according to leaflets of the sale "of a certain painting named the painters' shop or else the art chamber in which many different and distinguished painters have worked" ([van een seecker stuck schilderie genaempt de schilderswinckel ofte anders de cunstcamer daer differente veel ende frayen kunstenaers aen geschildert hebben) as a result of a condemnation of the court from December 12,1624. One of those opposed to the sale was Anneke Lemmens, widow of Jacques van der Lamen, as appears from one of the October 5 documents before notary N. Rooleeu.

78 When those sales were brought to an end, other ways were sought and found. The imported paintings were given to Amsterdam residents, who then sold them, with the excuse that a debt had not been paid. In reaction, the stipulation of permission for sales was extended from strangers to Amsterdam burghers, and the guild's overseers were permitted to prevent these sales 
if permission had not been granted. This time I cannot give examples, because thesuperintendant(concierge) Haringh, whose registers have not survived, conducted the sales. In olden times, three free annual markets allowed strangers to sell anything. However, this concept proved to be elastic. In a regulation published on January 31,1617 , the guild's overseers are not mentioned. Nevertheless they had probably complained. Outside the annual markets all sales of paintings that were not produced in the Seven Provinces were prohibited. Offenders would lose the paintings and be fined 25 guilders. A third of this amount would go to the Guild of Saint Luke. We have already seen an example of a similar trade in 1621. It was not the only case. Unsurprisingly, on October 21, 1623, a new regulation was decreed, which, apart from the 25 guilder fine, stipulated another fine of 12 guilders on every forfeited work. The guild's overseers controlled the works that were being imported for the annual fairs, which was only allowed eight days prior to the fair. After the fair the paintings had to be exported again within eight days or be stocked somewhere with the consent of the overseers. Further selling was fined 18 guilders, commissioning and selling thereafter were fined 25 guilders.

79 In 1626, it again proved possible to swindle at sales. For on September 16 it was decreed -- as an amendment to the regulation of 1623 -- that the auctioneers, that is, the superintendantand the delegates of the Orphan Chamber, were only allowed to conduct sales at the house of the seller or the house of the superintendant, and that paintings were not to be held up (opgehouden [raised up for all to see]) [to prevent an illegal insertion of paintings at the last moment]. Before the sale the overseers had to be given a list of all the paintings. The only exceptions were those works which were included in death- or insolvent estates.

80 We hear nothing more about foreign paintings. That buyers did not rely on Brabant so much anymore appears, for instance, from a letter from Elisabeth Stockmans dated April 1, 1632, to her sister Magdalena, who was about to move from Antwerp to Amsterdam: "Paintings can be bought in abundance here too. [We] nowadays have the best masters living here. There was a fair here last week, it was called the Vaste Marckt, and I saw a mass of beautiful pieces, also because I had someone with me who has knowledge about this, and at Pentecost there is another fair, since there is a fair three times a year. And although certain things could be a bit cheaper there with you, it saves the costs of transport. Not to mention the trouble you have of dragging it out and in the ships, which damages it severely" (Hier sijn oock schilderijen bij meenichte te krijgen. Hebben hier teegenwoordich van de beste meesters woonen. Was hier verleede weeck mart, dat men noemt de Vaste marckt, sach bij hoope fraye stucken, also een bij mij hadt die daer kennis van heeft en te Pinsteren ist hier weer mart also 3 mael 's jaers marckt is. En offschoon eenige dingen daer bij UL wat beeter koop soude mogen sijn, neemtde onkosten vant overvoeren weer wech. Behalleven UL de moeiten heeft van $t$ sleepen uit en in de scheepen daert oock seer mee versuckelt). It might be a coincidence, but these words were written just when Rembrandt settled in Amsterdam. One is under the impression, that the Shrovetide, Pentecost, and September fairs now offered many works for sale by Dutch artists. ${ }^{48}$

81 On October 17, 1630, a very important regulation was decreed. The guild's servant, who as we have seen, was already in attendance at some sales of paintings, now had to attend every sale. The visitation of the overseers of the guild -- three days ahead -- was no longer limited to paintings; books, prints, and art works (konsten) were added. From now on this applied for death estates, 
orphan sales, insolvent estates, and mortgages, which still led to swindles. At sales like these no other goods could be admitted.

82 One sees here how cautious one must be with the regulations of the heterogeneous guild. The Amsterdam painters quietly held their sales and kept on doing so. This regulation, then, was no doubt formulated with regard to the booksellers. In their business, the sale proceedings had a ruinous effect on trade, since large quantities were involved of which many dealers owned stock. In the archive of the booksellers' guild a few requests regarding this issue have survived $.^{49} \mathrm{Al}-$ though the overseers of the guild were opposed, on May 17, 1629, Broer Jansz got permission to hold an uitroep -- a sale, that is -- of his own books to pay his creditors, provided that this would be the last time.

83 Colette van de Keere, widow of Jodocus Hondius, and Jan Evertsen Cloppenburgh had acted as sureties for the father of Jan Jansen [Janssonius] from Arnhem and wanted to sell the surety they held. Jan Jansen himself also handed in a request. He finally got permission, on that same May 17, to sell up to 8000 guilders [worth of goods] but only among booksellers. He had to promise not to insert anything from anyone else, and "to use no one, no matter what sham, to boost the goods in sale, or as the booksellers say, to use as tame ducks, but that each will have to keep and pay for himself that which he will have bought" (niemant, onder wat pretext dat het sij te gebruycken om de goederen bij coop op te jagen, ofte gelijck de boeckverkoopers seggen tot tamme eenden te gebruycken, maar dat elck sal moeten houden ende betalen voor hemself dat hij gecocht sal hebben). The poor members' fund (bos) of the guild would receive 50 guilders for each violation of one of these conditions, and further direct as acknowledgment 18 guilders. If he were to organize another sale he would lose 200 guilders to the deposit fund, and the sale would be stopped. On October 20, 1640, at the guild's office, Jan Jansen nevertheless again got permission, because his wife had died and he had to pay his children their mother's inheritance. According to the catalogue that he handed in, he was allowed to sell up to the amount of 12.000 -- to 14.000-- guilders, however without intermission. If this sum was reached, he had to stop.

84 Finally, on July 26, 1657, Jan Jansz Brouwer, a bookseller who was about to quit, got permission from the burgomasters to have his books sold in a public sale by the messenger of the Orphan Chamber, provided that he would pay 25 guilders to the guild. Did Brouwer, who died not too long thereafter, keep running his book business after the sale, or did he spread the sale for too long? There might have been other offenders within the guild. In any case, on July $30,1658^{50}$ the overseers of the Guild of Saint Luke made a request to the court of justice. As a result, a regulation was decreed on August 31, 1658, which stipulated that anyone declaring he would cease doing business, and therefore would be selling, with the consent of the Guild, paintings, books, prints, and art works (konsten), had to do so with no interval and would not be permitted to open a shop afterwards.

85 Moreover, it was decreed that in such sales no one else's goods were allowed to be inserted. Whoever was targeted, it is clear that the regulation referred to the booksellers, and possibly to the art dealers, but not to the painters. In his article on Rembrandt's bankruptcy, J. F. Backer inaccurately linked that situation with this regulation. ${ }^{51}$ Others, such as White, adopted this theory. ${ }^{52} \mathrm{I}$ just have to point to the fact that this obviously did not apply to executive sales. 
It is possible, however, that the sale of Rembrandt's prints in December 1658 acted as a partial catalyst for a regulation of January 7, 1659. Since 1630, a guild servant's attendance at sales of paintings had been obligatory. Now his attendance was extended to the sales of statues, books, art, and, indeed, to prints, both at normal and at executorive sales, provided they consisted purely of those particular sorts of objects. Extensive stipulations were formulated about what the guild's servant had to do. One is under the impression that from then on the guild's servant -- rather than any secondhand dealer -- was to handle the storage of objects; the secondhand dealers had still been granted this job in 1654, after a dispute with the superintendantabout bankruptcy estates. ${ }^{53}$ The guild servant, and only he, should make his rounds among the guild's members with leaflets of the sale and catalogues.

The superintendant Haringh still worked according to the 1617 instructions; article 17 prescribed: "the advertising of leaflets at the usual places, the sales to be proclaimed by the city's announcer, addressing the slop dealers and those of the businesses of the most important goods on time" (de affictie van billeten ter gewoonlijcker plaatse bestellen, de vercoopingen bij de stadtsroeper doen vuytroepen, insinuatie aen de vuytdraechsters ende die van de neeringe van d'importantste goederen tijtelijk doen). It is possible that these old instructions and the storage duties of the secondhand dealers partly caused the low profit on print sales from Rembrandt's bankrupt estate. Still in 1666, the booksellers complained about the low profit on books that were sold executorially, as it was mostly secondhand dealers buying them.

88 On February 1, 1666, a regulation was established against rijffelarijen -- lotteries -- and secret sales in taverns. Since the regulation of 1630, those lotteries had only been allowed to take place with the consent of the burgomasters. This time the guild's servant was even authorized to write fines. However, by now the booksellers had formed their own guild. There was no question anymore about confusion between different sorts of businesses.

\section{The Guild of Saint Luke and the Booksellers' Guild}

It is understandable that the Guild of Saint Luke was not pleased to see the departure of its most prosperous members, the booksellers. After all, they chiefly fed the guild's pool (kas) with their fines. One of the motivations for opposition to the separation was that "several handworks had been united to second one another, and not so that the wealthiest would separate" (verscheidene handwerken samengebracht opdat het een het ander zoudde secondeeren en niet opdat het beste varende zich zou afzonderen). As we have seen, the separation went through anyway. However, some difficulties arose, principally about who would or would not fall under the jurisdiction of the new guild. ${ }^{54}$ On February 15, 1664, the overseers of the booksellers cited a number of persons to appear before the Commission of Small Affairs, whom they considered belonging to their guild, but who themselves apparently thought otherwise. Among them were book printers -- who until now had fallen outside the jurisdiction of the guild structure -- as well as booksellers, art dealers, and print sellers. Regarding the last two, I can state with certainty that among those were Salomon Savry, Frederick de Witt, Huigh Allart, Justus Danckerts, Nicolaas Visscher, Matthias Wynekes, Clement de Jonghe, and Jan de Vries. Of the twenty-five who were listed a few became members. ${ }^{55}$ Some refused nonetheless. The famous art dealer Clement de Jonghe and the lesser-known Jan Janse de Vries were cited at their third defaut -- non-appearance before the commission -- on Febrary 21, 1664, and both were ordered to pay 4 guilders, the amount that the guild was allowed 
to charge as a surety. Of course the two had to pay up, but they took their own measures. They wanted to stay within the Guild of Saint Luke and succeeded. On March 13, 1664, "to prevent as much as possible all the questions and disputes between the overseers of the Guild of Saint Luke and those of the booksellers' guild" it was announced that the "makers of playing cards, and paper art or print sellers who use the press" (om alle question ende oneenigheit tusschen de overluiden vant Saint Lucasgild ende die van de boeckdruckers ende boekvercopers zoo vele doenlijck voor te comen ... speelcaartemakers ende papierconst ofte prentwinckeliers, de pars gebruickende) now and forevermore would be allowed to choose the jurisdiction of the guild that they preferred.

As a result of this, Salomon Savry and Pieter Goos joined the guild of the booksellers on March 21, followed by Jacob van Meurs on March 22, Dancker Danckerts and Justus Danckerts on March 31, Nicolaas Visscher, Frederick de Wit, and Hugo Allart on May 8, Sara de Bari on May 12, the art seller Seger Tielemans on June 16, the mapmakers Jacobus van der Linden and Matthijs Wynekes on July 20,1664, and on an unmentioned date Jurrien Baeck, Pieter Mefferdt, and a person with an unreadable signature. The names of Clement de Jonghe and Jan Janse de Vries are missing because they did not join the booksellers' guild.

91 The booksellers tried to get what they wanted through the back door. Of course the sales of books fell under their jurisdiction because of the guild regulations of November 9, 1663. One finds there, worked out in detail, all the restrictions regarding sales, namely quitting (uitscheiden) or estate sales, which I discussed above. However, the art sales stayed under the Guild of Saint Luke, which had only two art dealers among its members, Clement de Jonghe and presumably the above-mentioned Jan Janse de Vries. The booksellers now petitioned the court of justice, in which they pointed out the undesirable situation concerning paper art and art plates and books and asked, for better maintenance of good order, to bring everything under their guild, the above-mentioned art dealers included. The booksellers' guild had influential members, and indeed a regulation was accepted on January 28,1666 , which was completely at odds with the regulation of March 13, 1664, however. Under point one, all art dealers and makers of playing cards were brought under the booksellers' guild, under point two the sales of paper art and art plates as well, while the sixth point stipulated that the sales could only take place with knowledge of the overseers of the guild.

92 Not surprisingly, a counter-request was launched by the Guild of Saint Luke. In response, the eldermen of the court of justice gathered advice from the overseers of the booksellers' guild. The two opposing perceptions reveal so many interesting details regarding the trade in drawings and prints, that I am publishing both, along with the regulation, in Appendix III. One of the most important points is that artists were wont to hold sales regularly, both of their own art and the art of others, this in full contrast with the practice of the booksellers. The choice of Clement de Jonghe and Jan Janse de Vries will, I assume, have had much to do with this.

93 Understandably, the January 28 regulation was revised. On June 8, the three points were changed. Again everybody was allowed free choice. Moreover, it was stipulated that the sales would reside under the guild to which the seller involved belonged. When Clement de Jonghe, who was immortalized by Rembrandt in an etching and owned a huge part of the artist's graphic oeuvre, died in 1677, his sale fell under the Guild of Saint Luke and that is the reason we do not know much 
about it. ${ }^{56}$ Concerning Jan Janse de Vries, I cannot even say if he is identical with the guild brother of that name from 1688 .

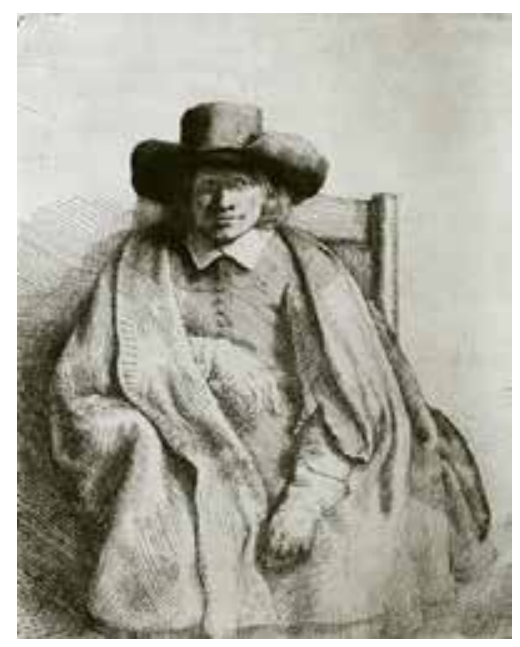

Fig. 7 Rembrandt, Clement de Jonghe, 1651, etching, 207 x $161 \mathrm{~mm}$. (B. 272)

94 It is certain, however, that all the big [paper] art sellers later on were members of the booksellers' guild, as shown in (among others) the registers of arbiters [goede mannen] from the years 1677 until 1716. Carel Allart, who was cited by both guilds in 1694, chose the booksellers' guild in December. ${ }^{57}$ The settlement for these art sales was not too effective, and problems kept occurring. It was only on January 29, 1704, after a dispute about the sale of art on paper from the collector Paulus van Uchelen, that a more convenient solution was found. ${ }^{58}$ At joint sales of books and prints the booksellers' guild would have the right of visitation if the prints remained under 100 guilders in price, while the Guild of Saint Luke would have that right if the books remained under that amount. If both rose above 100 guilders, each guild would visit its own section.

95 The visitation period of three days before the sale turned out to contribute to irregularities as well. By that time the sale had been advertised everywhere and could not be held back any longer. On February 9, 1701, this period was therefore not only stretched to eight days, it was also stipulated that prior to this period the concierges and the other auctioneers were not allowed to distribute sale leaflets. Nevertheless, this apparently did happen.

96 At the end of the seventeenth century, other difficulties for the guild resulted in regulations dealing with the glassmakers, about whom I will not occupy myself, and neither will I include anything on the eighteenth century, about which much can be read elsewhere. ${ }^{59}$

\section{APPENDIX I}

'De overluyde van t'St. Lukas gilt geven volgens ordre aen de grootaghtbare de heere burgermeesteren de lijste van haer gilde broeders so poorters als die vrijzeele hebbe als ooek die nalatigh sijn de zelve te vertoonen. (maart 1688)

\section{Poorters}


Frans Hendrickx, Cornelis Abramse de Ridder, Bartholomeus van Woerden, Jan van Hooghsteeden, Cornelis Willemse Spiers, Gilles Albertse Strijthout, Dirck Jansz Strijt van Schooten, Dirck Gijsbertse, Jan Jansz Oldenhoff, Jan van Munnickhuysen, Jan van Ambaght, d wed. van Willem Jansz Berbaas, Albert Clomp, Jan Warnarshuyse, Philip Abrams de Gaart, Pieter Hendrikse Baterij, Jan Groen, Pieter Andriesse Hulser, d wed. Johannes Schaets, Johannes Quaat, Abraham Decker, Jacob Janse Koornhuys, Hendrik Bulsinck, Mattijs van Cales, Tomas van Kessel, Ditmars Beverburgh, Jan Jacobs Koelewey, Frans Jansz, Gerrit Maggiels Hart, Jan Baltusse Distelbergh, Frederik Stam, Ijpe Andriesse Neeringh, Lourens Jansz van Hantwerpen, Jan Bartelse Heuckelman, Barent Pieterse, Abraham Davidts, Jan Jacobz Esau, Flooris Swartwout, Lucas Smull, Abraham Wilthuysen, Trijntie Fransz, Jan Jansz Worm, Harmen Jansz de Bree, Tobias Pieterse, Dirck van Voorst, Dirck Jansz Berghuysen, Harmen Geervliet, Jan Harmensz Nunnickx, Jacobs Evertse Henncklaar, Jan Franse, Johannes Sente, Bastiaen van Maale, Egbert de Gojer, Hendrick van Marken, d wed. van Antoni Scheepens, Jan Jansz Koek, Jan Witmont, Dirck Smitt, Alexander Brottier, Abrahams Opbens, Claes Jansz de Hont, Pieter Wiltschut, Salomon Ouduart, d wed. Wiltschut, Tobias Warda, Albert Meyeringh, Johannes Loerman, Sibert Andriesse Light, Clement Darshort, Claes Cetelhoet (doorgestreept), Willem Lourensz, Dirck Jansz van Zanten, Frederick Gerritz Bijlevelt, Reynier Moll, Alewijn Hendrickx, d wed. Jan Dirckx van Schooten, Pr. Peters ven Niedek, Hillebrant Vissen, Johannes Boerhoff, Migghiel Arentz Mouringh, Harmen Muller, Sagharius Webber, Rutger Terlouw, Dirck de Wilde, Jan Arente Looy, Frans Jansz Robbe, Huybert Dirckx Ham, Elbert de Haas, Abraham Miggiels, Isaack de Mortier, Gerrit Forties, Jan Cornelisse Ente, Rijkert Tierx, Johannes Seegers, Matteus Pietersse Tappe, Jacob Hoogeheyn, Jacob Lonrensz de Roode, Gerrit Forties,Hendrik Fokken, Jan Jansz van Keulen, Jan Davits de Leeuw, Gijsbert Jansz Seyst, Hendrick Arentz, Jan Smitt, Gerrit Valk, Abraham Blootelinck, Carel Allart, Hendrick Vissjager, Joachim Boorenmeeester, Pieter Tierkx, Hendrick Schulerus, Antoni Aght, Johannes de Kaersgieter, d wed. Claes Cooningh, Antoni van Leeuwen, Miggiel Smitt, Gijsbert van Maanen, Reynier Banier, Jan Jansz de Vries, Antoni Winter, Harmen van 't Veer, Dirck Jans Schuyt, Reynier van Zelm, Isaack Voegman, Jan de Rijk, Jan Bakker, Pieter Heromans, Adriaen Voorhoutel, Ignatius Luckx, Maurits Boederij, Adriaan Kuyper, Pieter Lourensz Ansloo, Pieter Terlouw, Jacobus de Best, Mattijs Moy, Jan Orgel, Lucas d Jongh, Abraham van Linsbeeck, Lukas Gerritsse Reght, Pieter Cranendonk, Jerriaan Nieuwboer, Simon Muller, Willem Sluys, Pieter Ardewijn, Lourens Woedenton, Jan Jansz van der Sluys, Cornelis Visser, Johannes Weninx, Antoni Grebber, David van der Plas, Johannes van den Avelen, Hendrick Brant, Pieter Mattijsz Groelaart, Cornelis Blauw, Harmcn Cleyn, Jan Barentse Schreeven, Jasper Waageman, Hendrick Klaasse Liskaljet, Willem Sweede, Philip Tiedeman, Jan Roosa, JanJansz van Lint, Korse Gijsbertse, Jan Vermeerte, Hoop Hartogh, Willem van der Cloet, Pieter van der Plas, Barnardus Dronrijp, Jan Jansz van Bakeren, Pieter Huyke, Jacob Smit Abramsz, Cornelis van der Laen, Pieter Jacobz Vernoek, Jan Jansz van Zelder, Frederick Rademaker, Denijs Rodeburgh, Gerrit van Houten, Hendrik van Streek, Abraham Jansz, Steven Vennekool, Johannes de Waaber, Niklaas van Eep, Lcendert Vogelesangh, Antoni Ardewijn, Harmen Egmont, Johannes Noortbeeck, Simon van der Schellinck, Jan Naghtegael, Christiaen Bleeker, Pieter Hoojcr, Abraham Voogelesangh, Barent Willart, Miggiel Musschart, Andries Willemse, Jacob de Vries, Antoni van Ceulen, Albert Brakel, Erik van Weerelt, Barent Graat, Jan Loopen, Frederick Waterloos, Matteus Mulder, Jan Vissingh, Cornelis Hartman, Frans Poeraet, Maria van Vreeden, Jan Jansen Hutjier, Siebert Tiepkes, Melghior de Hondecoeter, Jan Jacobz Holl, Pieter Penningh, Ludolf Bakhuysen, Johannes van Rijn, Jan Smeel, Han Hooy, Johannes Bott, Arent Friesenburgh, Pieter van Tooren, Claas Pieterse Bijl, Theophilus 
Bradlijn, Reynier Croese, Cornelis Hellemans, Mattijs de Vas, Jan Carssenbergh, Willem van de Reus, Isaack Vijvc, Cornelis Symonsz Wansbeek, Pieter Pieterse d Jonge, Gerrit van Amelant, Grietie Pieters, Cornclis van Harwarden, Siebere Pieterse, Jan Babtista Sierlant, Simon Christoffelse Pelle, Dirck Tijmensse Moll, Gilles Ruytenburgh, Christoffel Simons van Sleeswijk, Liebert Adriaanz van Nieuwenhooven, Jan Lammersse Helman, Isaak Pellekaan, Barent Engelbreght, Pieter Pieterse Bijl, Pieter Claasz Bijl, Willem Stam, Louis van der Broek, Rut Dircksen, Jan Ceyser, Jan Pietcrse Oly, Cornelis Ijsbrantz, Andries Andriesse Hollebuyk, Christiaen Huyberts, Pieter Christoffels van Hoorn, Simon Adriaensz Tromp, Baltus Gerritz, Gerrit Mouthaan, Cornelis Stoppegatt, Reynier Tiers, Cornelis Jansz Bakker, Jurriaen Kempen, Douwe Tiers, Fransoys Poledanus, Jan Brink, Homma Pieters, Harmen Janse Ban, Kasper Dirckse Gerards, Nicolaas de Vree, Jan Hooghvelt, Jan van Assen, Tierk Jacobs, Gerrit Claas Timmer, Johannes van Lint, Jan Jansz Jesuwijt, Jan Willemsz Roveen, Willem van Zanten, Jan van Moll, Johannes Vermout, David Joosten Ligterman, Hendrick van Duuren, Hendrick Dubbels, Jacob de Lange, Cristiaen Martense, Tomas Franse Woedenton, Jan Hendrickse Jaegvclt, Sijbrant van der Bent, Jacob Jacobs van Ruyne, Abraham Capiteyn, Alexander Rosenwel, Johannes de Broen, Willem Gerrits Hellendoorn, Barent Willekens, Jacob Ruysenaer, Nicolaas Barre, Jan Wiltingh, Jacob Mieringh, David van Kessel, Harmen Meijer, Robbert Corsse, Jan Veltman, Pieter Mansslagh, Mattijs Hendricks, Johannes Dekker, Jaques Teekens, Cornelis Brouwer, Johannes Lutma, Jan Hellewegh, Jacobus Bartolomeus de Ceulenaer, Evert Jansz Visser, Gerrit van Pruyssen, Johannes Andriesse Winkel, Johannes Both, Dirck van Hoofden,

Vrij Ceel:

Hendrik Stubbe, Pieter Smit, Claas Ketelhoedt, Hendrik Fockese, Anthonie Beukermich, Jan Cristoffelse, Pieter Barentse van Leyden, Arent Maes, Gijsbert van Toorn, Abraham Lens, Willem Vermander, Lucas Termijn, Willem Valk, Jan Mathijsse, de wedu Dirk van Stavoren, Gerrit Jasperse van Kniphuyse, Willem Roosekrans, Jan d Glasemaker, Johannes Luyken, Jan Jacobse Muscherd, Johannes Redding, Casper Motet, Pieter Barentse van Leyden, Abraham Lens, Willem Vermander,Arent Janse Swoortman, Willem Janse van Groeninge, Pieter Sijmense dc Boer, David Rericks, Jan Dirckse van Malta, de wedu Willem van der Norm, Pieter Gompelman, Lucas Gobert, Lambert Aertse, Cornelis van Beek, Jacob van Colen, Abram van Schagen, Willem Servaas, Pieter Schut, Fransojs de Pree, Gerard Larisse, Johannes Glauber, Wijbrant Janse, Catharina Muschert, Nicolaes Maas, Dirck Kock, Lambert van der Steegh, Lemoene de Lespejne, Arnhout Smit, Phlip Duvelt, Jan Penson, Reynier Banier, Jacobus Smit, Isaak Ouderkerck, Mathijs ter Voort, Eduart Coljier, Jaques Larisse, Abraham Sturk, Zijbrant Jillisse Groen, Jan Groen, Johannes Voorhout, Cornelis Janse Mensingh, Jan Pieterse van Jaarsvelt, Coenraad Koornhardt, Jan Remmerse, Jan Smit, Jacob Hackaff, Anthonie de Vos, Guiljam van de Goude, Willem van Ingen, Jan Naboret, Andries van Isendoorn, Jacob Adriaense, Timotheus de Graaf, Johannes Proch, Vinsent Motet, Cristoffel Asvalk, Johannes Isackse Lcvrje, Abraham de Rijp.

Nalatigh int vertoonen:

Silvester Bouman, Cornelis Dirckse Ejlander, Anthonie van Dalen, Roeloff Modeus, Arent de Burgh, Cornelis Colom, Abraham Bloemert, Jan Dirckse van Beck, Egbert Michielse Matte, Cornelis Stam, Johannes Reddingh (doorgestreept), Ziewert Pieterse, Arent de Burgh, Matheus 
d Schipper, Jeuriaen Groenhoff, Mathijs Michielse, Cristoffel Leman, Jan Bellardt, Dirck van Hoofden (doorgestreept), Gerrit Bramus, Bastiaen Stopendaal, Bartholomeus Eggcrs, Willem Standel, Evert Rokus van der Weul, Hendrik Brandt (doorgestreept), Johannes van Noordt, Jan Jansen, Johannes van der Nip, Job Berghejde, Gerard Berghejde (achter deze beide laatste staat: kleinc gchadt), Govert van der Leew NB groot vert., naar Italien, Phlip Koningh NB, Johannes Kolé, Willem Sluys, Jan Navret, Huybert van den Appel, Crijn Gerritse Bosman, Mathijs Navre, Johannes Hugtenburgh, Cornclis Willemse, Dirk Daniels, Martinus van der Hoeve, Johannes Isaaks, Barent Gaal, Dirk Broek, Hendrik de Jongh, Johannes van Kuyk, Cornelis Willemse, Jacob Vrocgman, Hendrik, Everse Beserman, Johannes de Ram, Pieter Rodingh.

Ondertejkent van de overluyden van St. Lucas Gildt Pieter Penninck, Jan Hooy, Pr. Pieterse van Niederk, Dirck van Voorst, Jan de Kaersgiet

\section{APPENDIX II}

Conditien ende termijnen waarnae de boecken van Barent Aeriansz sullen werden vercoft luyden als volcht.

Alle coopers sullen weten dat dese boecken vercoft sullen werden in manieren ende op termijnen als volcht.

So wie coopt bedragende onder de somme van eenhondert gulden deselve sullen betaelen op ses weecken eerstcomende.

Ende wie dat coopt bedragende ter somme van twee ofte meer hondert guldenen die selve sullen op drie maenden betaelen de somme van hondert guldens ende dat alle drie maenden achtereenvolgende tot dat het laetste betaelt sal sijn ende daervan teyckenen obligatie tot believen van Barent Adriansz.

Alle boecken bij Barent Adriansz gedruckt ofte in den druck becosticht, sal hij in den tijt van drie maenden tgene deffect bevonden wert volmaken off met ander in gelijcke waerde voldoen, maer aen ander ende vremde materien niet gehouden sijn.' (March 12, 1612).

'Den 15 maertii 1638 zijn de naergelaten boecken, kaerten, konstplaten, houte figuren achtergelaten bij Michiel Colijn vercocht ende dat op de naervolgende conditien.

1. Eerst ende voor al datt degheene die gelieven zal eenighe goederen in deese uitroep te koopen tot der somme toe van tweehondert guldens incluys sal gehouden wesen te betalen binnen ses weecken.

2. Ende zoo jemandt quaeme te bestede boven de tweehondert guld. tot der somme toe van zes- hondert guldens mede incluys sal genieten den tijt van zes maenten te betalen van de selve somme alle dry maenten een gerechte helft.

3. Ende koopende boven de geseyde ses hondert guld. tot der somme toe van duysent guld. sal 
betalen binnen sjaers alle vierendeel jaers een gerechte vierde.

4. Wel verstaende datt soo iemandt quame te besteden boven de geseyde duysent guldens tot der somme toe van twee duysent ofte daer boven sal betalen binnen twee jaeren alle vierendcel jaers een gerechte achtste.

5. Maer kopende boven de duysent guldens ende niet monterende tot de voorschreve twee duysent guld. sal sigh hebben te reguleren als van de twee ende ses hondert guld. in de eerste ende tweede articulen van dese conditien is geseyt.

6. Dogh wel verstaende dat jeder een gehouden sal zijn te geven obligatie ende te stellen suficante borghen ten genoeghen van den vendumr. ende dat onder renuntiatie van de benefitien ordinis \& excussionis.

7. Voorts soo seggen de verkopers, dat alle boecken die geveilt sullen werden, na haer beste weten vol ende compleet zijn, doch indien iemandt namaels eenighe pretensie dierhalven wilde maken ende begeeren sij tot gheen volmaeckinge gehouden te weesen.

8. Al het ghene oock op de tafel sal geleyt zijn, moet na dat de klop gegaen is voor gelevert gehouden worden.

Finis

\section{APPENDIX III}

(After February 1, 1666) 'Copye van een request van de overluyden van t St Lucasgilt aen de E. Heeren van den Gerechte van Amsterdam.

Geven met behoorlijcke eerbiedigheyt te kennen de overluyden van 't St Lucasgilt, hoe dat de boekedruckers ende boekverkopers op haer versoek, van haer supplianten gilt sijn gesepareert, op 't voorgeven dat sij beyde te saemen een genoeghsaem getal waeren tot een apart gilt, en dat sijluyden, sijnde gesepareert van alle d'andere hun gilt alsdan bequaemst souden kunnen voorstaen, waerop UE Groot Achtb. en mijne Heeren van den Gerechte, bij haer willekeure op den 20 jan. 1662 gelieft hebben de boekdruckers en boekverkopers tot een apart gilt te stellen, met het welcke sij hun niet tevreden houdende, volgens haere gewoonte, maer hebbende getracht buyten alle reden, jae tegens haer vorigh versoek, de konstverkopers en speelkaertemaekers onder haer gilt te trekken, die nochtans van outs af altijts onder St Lucas gilt zijn geweest, eyndelijck soo veel hebben te wege gebracht, dat UEd. Groot- achtb. die verschillen in haer faveur, door haere onbehoorlijcke instantie hebben gelieven voor altoos vast te stellen bij willekeure van dato 13 martii 1664 luydende als volght (hier volght die willekeure van woort tot woort, voor so veel die de konstverkopers en speelkaertmakers raekt) ende alhoewel sijluyden hadden behooren hun daermede vergenoegcn te laeten, so ist echter sulcks, dat sij onlanghs buytcn eenige Kennisse van haer supplianten, en sulcks tegen alle billijckheyt so veele hebben geobtineert, dat sij so wel de overluyden als oock alle de gildebroederen van St Lucasgilt (die al heel geen keure hebben om te gaen daer sij willen) haer gilt hebben subject gemaekt, ende allen denselven, ende een yeder van 
hen, ten halven onder haer separaat gilt getrockcn met het $1 \& 2$ articulen van de willekeuren hier annex en insonderheyt met het 6e articul. Edoch gemerckt sijlieden een apart gilt zijn, soo kunnen dacrom de voors. Respect articulen bij t St Lucasgilt onmogelijck onderhouden worden, dewijle t' allen tijden haere gildebroeders, so schilders als andere konstenaars, die volgens d'articulen van haer gilt mogen door d'afslagers verkopen alle haere konsten, en al verkregen hebbende consent bij de overluyden van St. Lucasgilt, om maer alleen haer schilderijen te verkopen, soo souden sij echter genootsaekt sijn, noch de verkopingh van haere papieren en andere konst, die sijselfs in al haer leven gemaekt hebben (soo van tekeningen, modellen, printen en constplaeten, en wat sij voorders door lanckheyt van tijdt hebben versamelt soo in Italien als elders) te versoeken aen de overluyden van de boekdruckers en boekver- kopersgildt, welcke haere formele partijen sijn in voegen, dat die gene die alleen onder $t$ St Lucasgildt behooren, soude als voren met een en het selve dat haer eygen doen is, moeten subject en sorterende sijn onder twee gilden. Waeruyt in ' $t$ toekomende niet als alle onlusten en continuele moeyelijckheden te resulteren staen, te meer alsoo de boekdruckers en boekverkopcrs en eenige weynige printwinckeliers, die oock maer verkopende winckelgoet, gebouwen, Franse printen en meest kaerten, geen grondige kennisse hebben van de voornaemste papiere konst, immers soo veel niet als die deselve door sijn eygen inventie maekt, en door lanckheyt van tijdt versamelt heeft, als mede door haer dagelijcksen handel meestendeel altemael de fraeyste papieren konstverkopers sijn, gelijck sulcks bij alle heeren die lief- hebbers van raere papiere konsten sijn genoegh is bekent, soo dat de selve ordinaris in sterfhuysen en scheydingen onder vrienden van de voorn. kunst gebruyckt worden. Soo is dierhalven haer supplianten ootmoedigh versoek (om eenmael een vasten voet te hebben, en UEd. Grootachtb. deesen aengaende niet meer moeyelijck te vallen) dat UE Grootachtb. gelieven de voors. weynige papieren konstverkopers tevoegen tot en onder het St Lucasgilt daer sy doch inderdaet, om redenen als voren volkomen met al haer doen annex sijn. Edoch indien UEd. Grootachtb. haer suppl. dit haerbillijck en rechtmaetigh versoeknietsouden gelieven toe te staen, gelijck sij vertrouwen van jae, dat dan immers de gemelde 1. 2. en 6. articulen sodanigh werden verandert, gelijck het is geweest t'sedert het publiceren van de voors. willekeure, naementlijck, dat voortaen alle venditien van de voors. Papieren konst en konstplaeten aengaende, ende alle diegenedie onder ' $t$ St Lucasgildt syn, als oock die, welcke volgens de voors. Willekeuren daer alrede onder bebben gekosen, en tot allen tyden noch sullen kiesen alleen sullen syn en blyven onder 't voors. St Lucasgilt sonder eengige andere gilden te kenne. Gelijck oock in tegendeel alle de venditien van papieren konst en konstplaeten aengaende die hunselven gestelt en verkosen hebben te sijn onder ' $t$ boekdruckers en boekverkopersgildt, en die naemaels noch sodanigh verkiesen, sullen sijn en blijven onder ' $t$ voorsch. Boekdruckers en boekverkopers gildt, op dat also alles met beter gerustheyt en ordre mogt toegaen, welck doende...'

'Onderdanigh bericht van de overluyden van het boekverkoopers, boeckbinders en boeckdruckersgilt' '20 april 1666 Aen de Eed. Groodtachtbare Heeren mijne Heeren van de Gerechte der stadt Amsterdam. Gesien bij d’overluyden van 't boeckvercopers, boeckdruckersgilde en papier kunstverkopers hierter stede seekere requeste aen U Eed. Groodtachtbaerheden overgegeven, op den name van de overluyden van 't Lucasgilde, ende geexamineert den inhoude van dien, bevinden het versoeck van 't selve te bestaen daerin dat nu weder verandert souden mogen werden, het eerste, tweede ende seste articulen der ampliatie op de keure en ordonnantie van de supplianten maer enige weecken geleden near lange deliberatic door mijne welgemelte heeren gearresteert en gepubiceert, daerop de overluyden van de boeckverkoopers, boeckdruckers en 
papierkonstverkopers haer Eed. Groodtachtbaerheden onderdanichlijk dienen van haer bericht, te weten: dat sij (voorbijaende de onheusche ende confuse maniere van versoeck) seer ongherijmt bevinden de redenen en motieven die tottet obtineren van 't selve werden bijgebracht, namelijck dat een schilder soo die mede papiere konst heeft, als hij die oock soude willen publicq verkoopen onmogelijck soude tonnen onderhouden de voorn. articulen, ter saecke hij dan subject soude wesen twee gilden: Item dat de papiere konstverkoopers wijnich gemeenschap offte kennisse met of van schilders papierkonst hebben: ende dattet toestaen van $t$ selve versoeck een middel soude wesen om eenmael een vaste voet te stellen dat U Ed. Groodtachtbaerheden daer over niet meer lastigh gevallen souden mogen werden. Want belangende de eerste reden, soo en heeftet geen onmogelijckheyt van gepractiseert te tonnen werden, dat papiere konst van schilders als men die publicq soude willen verkopen gevisiteert soude werden door de rescribenten, schoon dat de schilderijen door de overluyden van het St Lucasgilt worden achtgeslagen: naerdemael voor desen, selffs doen de respective overluyden en ambachten off neeringen noch onder een gilt waren in een en het selve sterffhuys de schilderijen door de overluyden-schilders en de boecken door de overluyden-boeckverkoopers apart besichtight sijn geworden, en elck bysonder betaelt, even gelijck nu oock in de papierkunst en print- boecken geschiedt en door Mijnee Heeren van den Gerechte om seer goede oorsaecken soodanigh gestatueert is. Vorder aengaende de tweede reeden, soo heeft het al soo wijnich bescheydt, dat de requestanten voor aen in haer request, den Heeren tegen de waerheyt soecken wijs te maecken, dat de papiere konstverkoopers klijne kennisse off wel geen gemeenschap weegens de schilders papiere konst hebben en dat se op $t^{\prime}$ eynde van haer request versoecken, dat deselve papieren konstverkopers evenwel onder de overluyden van de schilders souden getrockcn werden, bysonderlijck daer sij selffs seggen, dat se maer gebouwen, Fransse printjes en kaertjens verkoopen, twelck het naeste is tot de boeckverkopers, die alle dat selve mede in hare winckels hebben. En eyndelijck betreffende de laeste reden, soo kan door UEd. Groodtachtbaerheden lichtelijk affgenomen werden, dat die mede seer sober, jae geheel tegen de requestanten is. Gemerckt de rust en vreede ongetwijfelt beter en seeckerder sal sijn in de stant daer de saecke nu in is gebracht en seer wel bevonden wert als weder veranderinge te maecken, bysonderlijck als geconsidereert wort de goede ordre die Mijne Heeren van den Gerechte hierin hebben gelieven te observeren. Eerst de kunstverkopers \& speelkaertemaeckers in hare vrijicheyt te gegeven waer se hem best vinden te keeren, en alle daer op overgegaen sijnde bij de rescribenten op twee nae uytte papiere konstverkopers, daernae die twee mede tot alle de andere te voegen, twelck immers veel redelijcker was als dat alle de andere hen nae die twee souden hebben moeten reguleren en dierhalven off deselve noch gesepareert te laten. En dierhalven (onder reverentie) zeer onghefondeert ende buyten alle reeden is dat de overluyden van 't Lucasgilt nu noch derven versoecken, dat de keure voor een yegelijck weder zoude openblijven, soo wegens papiere-konst-venditien als papiere-konst-verkopers, om hem te vervoegen tottet een off tottet ander gilt daer ' $t$ hun goeddunckt. Maer dewijle door de requestanten niet en kan werden ontkent off dit soude continuele confusie end disput causeren: en notoir is, dat de papiere konst- verkopers oock alsoo wel haer verstaen op de papiere korist van de schilders als de overluyden van 't Lucasgilt en om op alles wel acht te geven, onder de rescribenten oock altijt een papiere konstverkooper door Mijne Heeren van den Gerechte gestelt wert, midsgaders geen onmogelijckheyt noch verhinderinge en geeft int houden van de venditien, off de rescribenten de papiere konst van schilders visiteren en de overluyden van ' $t$ Lucasgilt de schilderijen, waerdoor nochtans de schilders selffs geen twee gilden onderworpen sijn. En bovendien alleen het argument van de requestanten geensins sluyt, dat om casuele verkopen van eenigh goet wegens 
personen die van zoodanige waren geen winckel en doen, en daerom- trent echter oock goede ordre is, UEd. Groodtachtbaerheden souden gaen veranderinge maecken om- trent personen die ' $t$ hare professie is tot verwarringe en onrust selffs in poincten die onlangs soo circum- spectelijck, voorsichtelijck en tot goede ruste van de gildebroeders sijn gewillekeurt, na de rechte waerheyt en gront der saecke, terwijle papiere konst en plaetten, als mede de winckelhouderen van dien veel meer gemeenschap hebben mette boeckverkopers en boeckdruckers als mette ambachten van ' $t$ Lucasgildt, als schilders, borduijrwerckers, beelthouwers, glasmakers etc. Dierhalven soo oordeelen de rescribenten (onder reverentie) dat den requestanten versoeck is teenenmael ongefondeert en dat oversulcx de saecke behoorden te worden gelaten in de staat daer se door eygen verkiesinge van alle, met toevoeginge alleen van twee persoonen, seer wijsselijk bij Mijne welgemelte Heeren is gebracht, en noch gerustelijck sonder eenige oppositie ofte difficulteyt gepractiseert wert daer nochthans bij weder ofsondcringe de overluyden van het Lucasgilt geduyrigh de papiere konstverkopers souden partije sijn en soecken te prejudicieren, waerom de requestanten suppliceren dat ' $t$ versoeck mach werden affgeslagen aengesien daerdoor niet dan groote verwarringe en oneenigheyt onder de beyde gilden en geen cleyne moeyelijck- heyt voor de Heeren gecauseert souden werden. Dit doende \&c.'

For the ordinance of June 8, 1666, compare Noordkerk, Handvesten, booksellers' guild (p. 1219), where only the date of publication, July 16, 1666, is given, not that of the arrest by the college of sherrif, burgomasters, and aldermen on June 8,1666 . The six points mentioned here originally were points 3-8 from the ordinance of January 28, 1666, which was published on Febrary 1, 1666. Point 6 (later 4 ) was changed, points 1 and 2 were canceled.:

28 januari 1666 'Boeckvercopers, boekdruckers, boekbinders, kunstvercopers, speelcaertmakers.'Mijne heeren van den gereghte hebben, om goede redenen en insighten, amplierende en ten dele altererende de keure en ordonnantie, raeckende de boeckvercopers, boeckdruckers en boeckebinders alhier gemaeckt op den 9e october (moet zijn 9e november) anno 1663 gepubliceert verstaen en geordonneert, zoo als hare EE doen bij desen:

1. Eerstel. dat van nu voortaen de kunstvercopers en speelcaertemaeckers mede gebraght zullen worden en begrepen sijn onder 't gilt van de boeckvercopers, boeckdruckers en boeckebinders voors.

2. Gelijck mede tot het zelve gildt gebraght zullen worden en behoren, de venditien van papiere konst ende konst-platen.'

'6. Dat geene vercopingen van boecken noch oock van papiere off konst-platen gedaen sullen worden, tzij door de concerge ofte de andere aflslagers dan met kennis van den overluyden van dit gilt.'

Dit laatste artikel luidde sedert 8 juni 1666 als artikel 4:

'Dat geene vercopingen van boecken, noch oock van papiere konst, ofte konst-platen, van die van die volgens willekeure van den 13e Martii 1664 gecosen hebben, ofte noch sullen comen te kiesen, te willen wesen onder het boekvercopers en niet onder t' St Lucasgilde, gedaen zullen mogen 
werden, tzij door de concherge, ofte de andre afslagers, dan met kennis van den overluyden van dit gildt.'

\section{List of Illustrations}

Fig. 1a Guild Funeral Medallion of Rembrandt (recto), 1634, diameter 28 mm. Rembrandt House Museum, Amsterdam.

Fig. 1b Guild Funeral Medallion of Rembrandt (verso), 1634, diameter 28 mm. Rembrandt House Museum, Amsterdam.

Fig. 2 J. C. van Royen (after an unknown portrait), Portrait of Thomas Haringh, from the De Moor Family Album (Legaat van Beresteyn). Ikonographisch Bureau, Rijksbureau voor Kunsthistorische Documentatie The Hague, inv. no. 203166 (Photo: Collection Rijksbureau voor Kunsthistorische Documentatie, The Hague).

Fig. 3 Rembrandt, Thomas Haringh (“The Old Haringh”), ca. 1655, drypoint and burin, 195 x 150 mm. (B.274)

Fig. 4 Handbill for the Auction of Rembrandt's Graphic Art Collection, December 20, 1658. British Museum, London.

Fig. 5 Rembrandt, Sketch of Raphael's Portrait of Baldassare Castiglione (recording its sale from Lucas van Uffelen's collection, April 9, 1639), 1639, pen and brush in brown, white body color, 163 x 207 mm. Graphische Sammlung Albertina, Vienna, inv. no.8859.

Fig. 6 Rembrandt, Pieter Haringh (“The Young Haringh”), 1655, drypoint and burin, 195 x 146 mm.(B. 275)

Fig. 7 Rembrandt, Clement de Jonghe, 1651, etching, 207 x 161 mm. (B. 272)

\section{Acknowledgements}

Jasper Hillegers generously undertook this challenging translation, collaborating with the archivist S.A.C. Dudok van Heel who had worked alongside Juffrouw van Eeghen at the Gemeente Archief (Stadsarchief), Amsterdam, for many years. We are grateful for Dudok van Heel's extensive knowledge of the archives during his years there, as well as his expert help with many of the article's details. In addition, we express a debt of gratitude to art historian Joy Kearney for her work during the early stages of the translation.

Hillegers was contributing author of The Jewish Rembrandt: The Myth Unraveled, 2008, and has also contributed to Tableaux flamands et hollandais musée des beaux-arts de Rouen, 2009; (elebrating the Golden Age, 2011 (by Anna Tummers); and Gedrukt tot Amsterdam, Amsterdams prentmakers en uitgevers in de Gouden Eeuw, 2011. He is currently an associate at Salomon Lilian BV, Amsterdam. 
*The notes of the 1969 publication have been updated in this translation. For the original notes, click on the link to the PDF file.

${ }^{1}$ I. H. van Eeghen, "Schilders of Sint Lucasgilde," in Inventarissen der archieven van de gilden en van het brouwerscollege (Archief der Gemeente Amsterdam, 1951),103-8.

${ }^{2}$ For Herman Noordkerk, see the entry in the Nieuw Nederlandsch Biografisch Woordenboek: http://www.dbnl.org/tekst/molh003nieu10_01/molh003nieu10_01_0938.php.

${ }^{3}$ Frederik D. O. Obreen, "Het Sint Lucasgild te Amsterdam," in Archief voor Nederlandsche Kunstgeschiedenis (Rotterdam, 1877-90), 3:89-196; H. Noordkerk, Handvestenofte Privilegien ende Octroyen: Mitsgaders Willekeuren, Costuimen, Ordonnantien en Handelingen der stad Amstelredam, 5 vols. (Amsterdam: H. van Waesberge, S. en P. Schouten, 1748-78); J. G. van Dillen, Bronnen tot de geschiedenis van het bedrijfsleven en gildewezen van Amsterdam, 3 vols. (The Hague 1929-74). ${ }^{4}$ This gives the guild ordinance of 20.7.1573, with bij art. 1 ampl 14.1.1624, bij art. 3 ampl. 27.1.1617, bij art. 4, 6, 8, 9 ampl. 16.9.1626, bij art. 18 ampl 15.8.1579, ordinance 10.11.1608, ordinance 10.10 .1613 , and finally the ordinance of 24.5.1619, with a renewal of 24.3.1623 against the sale of songs on the street and in public places.

${ }^{5}$ I. H. van Eeghen, De gilden: Theorie en praktijk (Bussum: C.A. J. van Dishoeck, 1974).

${ }^{6} \mathrm{P}$. Scheltema, "Schilders die te Amsterdam poorters zijn geworden, tusschen de jaren 1584 en 1605," in Frederik D. O. Obreen, Archief voor Nederlandsche Kunstgeschiedenis (Rotterdam, 187790), 2:272; P. Scheltema,Rembrand: Redevoering over het leven en de verdiensten van Rembrand van Rijnmet eene menigte geschiedkundige bijlagen meerendeels uit echte bronnen geput (Amsterdam: P. N. Van Kampen, 1853), 68-71; P. Scheltema, "Namen der schilders, die in de tweede helft der zeventiende eeuw te Amsterdam poorters zijn geweest," Aemstels Oudheid 4 (1861):59-70. ${ }^{7}$ Van Eeghen disregards the fact that in 1652 huge expectations arose among painters regarding commissions for the new City Hall for which citizenship was obligatory. See, for example, A. Blankert, Kunst als regeringszaak, exh. cat. (Amsterdam: Royal Palace, 1975), 19. ${ }^{8}$ SAA, no. 367.A, Archief Burgerweeshuis, 1.2.3.3., 452B. Compare W. F. H. Oldewelt, "Een beroepstelling uit den jare 1688," in Amsterdamsche Archiefvondsten (Amsterdam, 1942), 172-76. ${ }^{9}$ W. F. H. Oldewelt, "Het Sint Lucasgilde," in Oldewelt, Amsterdamsche Archiefvondsten (note 9), 84-91. This paragraph corrects information in the original text.

10 "Een belangrijke ontdekking," Architectura 21(1913): 339-40 (conversation with W. K. F. Zwierzina). See also J. F. Backer, "Les tracas judiciaires de Rembrandt," Gazette des Beaux-Arts 66 (1924): 38-39.

${ }^{11}$ See Walter L. Strauss and Marjon van der Meulen, with the assistance of S. A. C. Dudok van Heel and P. J. M. de Baar, The Rembrandt Documents (New York: Abaris Books, 1979), 113-14 $(1634 / 10)$.

${ }^{12}$ For a recent survey on kladschilders in Leiden, see P. Bakker, "Crisis? Welke crisis? Kanttekeningen bij het economisch verval van de schilderkunst in Leiden na 1660," De Zeventiende Eeuw 27, no. 2 (2011): 232-69.

${ }^{13}$ Katherine Fremantle, "Cornelis Brise and the Festoon of Peace," Oud Holland 69 (1954): 222-28. ${ }^{14}$ A. von Peltzer, Joachim von Sandrarts Academie der Bau-, Bild- und Mahlerey-Künste von 1675: Leben der berühmten Maler, Bildhauer und Baumeister(Munich, 1925), 203.

${ }^{15}$ Van Dillen,Bronnen tot de geschiedenis(note 4), 2:254 (Not. Van Banchem).

${ }^{16}$ Van Dillen, Bronnen tot de geschiedenis, 2:1356 (Not. Laurens Lambeti).

${ }^{17}$ For the period 1614-59, a total of ten fine painters are known to have functioned as overseers. 
Four of them held the function more often than the others: Cornelis van der Voort (twice), Nicolaes Elias Pickenoy (twice), David Colijns (four times), and Dirck Pietersz Wittepaert, alias Bontepaert (twice). For the period 1614-15: Cornelis van der Voort (I. H. van Eeghen, "Het Amsterdamse Sint Lucassgilde in de 17de eeuw" [see note 1], 70). For 1616-17: Jan Tengnagel (M. J. Bok in Dawn of the Golden Age: Northern Netherlandish Art 1580-1620, exh. cat., edited by G. Luijten et al. [Rijksmuseum, Amsterdam, 1993], 318); 1619: Cornelis van der Voort (J. Briels, Vlaamse schilders en de dageraad van Hollands Gouden Eeuw [Antwerp, 1997], 402). For 1628-29: David Colijns, Nicolaes Eliasz Pickenoy (N. de Roever, "Pieter Aertsz, gezegd lange Pier, vermaard schilder," Oud Holland7 [1889]: 19; Van Eeghen, "Het Amsterdamse Sint Lucasgilde" [note 1], 70-71, Briels 1997, 368). For 1630-31: Isaac van Conincxloo (Van Dillen, Bronnen tot de deschiedenis (note 4), vol. 2 [1933], no. 1356), Dirck Pietersz. Wittepaert (alias Bontepaert) (Van Eeghen, "Het Amsterdamse," 71). For 1634: François Venant (Briels 1997, 394). For 1634-35: David Colijns, Nicolaes Eliasz Pickenoy (A. Bredius, Künstler-Inventare; Urkunden zur Geschichte der Holländischen kunst des XVIten, XVIIten und XVIIIten Jahrhunderts [The Hague, 1915-22], 4:1230; Briels 1997, 368). For 1636-37: Dirck Pietersz. Wittepaert (alias Bontepaert), Gilles d' Hondecoeter (Van Eeghen, "Het Amsterdamse," 71). For 1644-45: David Colijns, Jan de Kaersgieter (A. Bredius, "Rembrantiana," Oud Holland 28 [1910]: 9). For 1654-55: David Colijns (Briels 1997, 314); 1658-59: Dirck Santvoort (zoon van Bontepaert) (Van Eeghen, "Het Amsterdamse," $71)$.

${ }^{18}$ SAA, no. 5061; Rechterlijk Archief, 686, p. 34. This request must date from between 1687 and 1701 , in which year the ordinance of February 9 shows said objections to have been removed. The direct cause of this regulation was not given in the request, for on the back there is noted "nihil." ${ }^{19}$ Van Eeghen stated in her original text thatAbraham Gerritsz was perhaps identifiable with the glazer of the same name, who married in 1615 . However, it seems unlikely that a glazer, who should be a member of the guild, would act as their servant.

${ }^{20}$ According to the daily Notulen of the burgomasters, 1668-71, Toonhuysen was on 19.2.1670 "gedeporteert over sijn quaet comportement met drincken, te ontfangen en niet wederom te geven van andermans gelt etc." On 25.2.1670, the successor in this office was chosen by burgomaster Pancras.

${ }^{21}$ See J. E. Elias, De Vroedschap van Amsterdam (Haarlem: Loosjes, 1903/5), 1:463.

${ }^{22}$ In order to avoid too many endnotes, let me list the following sources, which can mainly be found in the Groot Memoriaal [the following text has been reprinted exactly as it appears in the original Dutch]. [See SAA, no. 5032, Groot Memoriaal]I 321: 30.10.1544; II 52: 29.5.1554 (ord. secr.); II 148vo en 180vo (borgtocht boden); II 266 (instr. boden 1617 met borgtochten); II 271 vo: (instr. concierge 1617); III 18 (accord secr. en boden 1645); III 54, 57 en 61vo (instr. boden 1627 met borgtochten); III 189 (1638 verk. O.I.Compagnie en 1639 verk. van Uffelen); III 205vo. (instr. eerste bode 1640);.III 244 (accord secr. en bode 1645); III 264 (borgtocht bode); III 270vo (verbod rijffelrijen 1648); IV 25vo (rekwest afsl. Nieuwe Brug 1654); IV 77vo, 109vo en 141vo (borgtochten boden); IV 145vo (rekwest Renialme 1657); IV 154vo en 177 (kwestie tussen afsl. over de koopmanschappen 1658); V 14 (ben. adjunct concierge 1660); v 82 (borgtocht bode); VI 35vo en 143 (verrekening afsl. Nieuwe Brug (1671); VI 35vo en 256 (borgtocht boden); VII 107 vo (kwestie betr. afslaan van granen 1629 etc.). Daarnaast o.a. nog Keurboek [SAA, no. 5020] E 155 (berk. inboedels), Keurboek K 177 en 177vo (betr. afslagers Nieuwe Brug 1632-1657) en M 53 vo (1/2\% op verk. van koopmanschappen ter wille van stadsnoden 1649). Port Weeskamer met stukken betr. boden, o.a. instr. van 3.7.1636, en vooral de port. Noordkerk Arch. Slingelandt (Alg. 
Rijksarchief) no. 410.

${ }^{23}$ J. F. van Bemmelen, “Indentificatie van familie-portretten," Jaarboek Amstelodamum 26(1929): 59-78; W. F. H. Oldewelt, "Rembrandt' etsen 'de oude' en 'de jonge Haringh, Jaarboek Amstelodamum 27 (1930): 175-78; SAA, no. 5039,Thes. Ord., 465, 16 and 466, 12 and 26. ${ }^{24}$ The portrait was made by Miss J. C. van Royen after an unknown portrait. See J. F. van Bemmelen, "Het album De Moor," Maandblad De Nederlandsche (1927): cols. 65-73. The Haringh portrait is illustrated in that article (col. 69, no. 20) as one of forty-six drawings after family portraits. Jhr. Mr. Dr. E. A. van Beresteyn bequeathed genealogical material to the Dutch state; see Jaarboek van het Centraal Bureau voor Genealogie en het Iconographisch Bureau 7 (1953): 15-81, fig. on p. 77: “MOOR, de. Album de Moor. Portretten en wapens." See also R. Ekkart and E. Ornstein-van Slooten, Oog in Oog met de modellen van Rembrandts portret-etsen/Face to Face with the Sitters for Rembrandt's Etched Portraits (Amsterdam, Museum het Rembrandthuis, 1987), cat. 46. Haringh was related to the van der Hagen/de Moor family through his wife.

${ }^{25}$ SAA, no. 5072, Commisaren Desolate Boedelskamer, C 5, 170, 223, 225, 234, and 254.

${ }^{26}$ For Adriaen Hendricksz de Wees, see S. A. C. Dudok van Heel, "De Kunstboeken van Adriaen Hendricx de Wees," Maandblad Amstelodamum 66 (1979): 43-44.

${ }^{27}$ For Jan Pietersz Somer, see S. A. C. Dudok van Heel, "Jan Pietersz Zomer (1641-1724), makelaar in schilderijen (1690-1724)," Jaarboek Amstelodamum 69 (1977): 89-106.

${ }^{28}$ F. Lugt, Les marques de collections de dessins et d'estampes (Amsterdam, 1921), 272-77, with details about this agent. More details can be found on the agent Thomas Wachtels, who occupied himself with art, among other things, in Clara Bille, De tempel der kunst of het cabinet van Braamcamp (Amsterdam: d Bussy,1961).

${ }^{29}$ Cornelis Hofstede de Groot, Die Urkunden über Rembrandt(1575--1721)(The Hague: M. Nijhoff, 1906), no. 183.

${ }^{30}$ For Jan de Blocq, see S. A. C. Dudok van Heel, “De schilder Claes Moyaert en zijn familie," Jaarboek Amstelodamum 68 (1976):. 39-40.

${ }^{31}$ SAA, no. 573, Weeskamer, 2.10.2.6, bundle 934.

${ }^{32}$ I. H.van Eeghen, “Uitdraagsters 'tzij man of vrouw," Maandblad Amstelodamum (August-September 1969): 102-10.

${ }^{33}$ Compare, for example, art. 11 in an ordinance of October 29, 1686, concerning sales of manufactured goods, where a "boedel of cargazoen" is mentioned (Noordkerk, Handvesten [note 2], 2:513). Whether Sandrart's own sales of paintings and prints upon his departure from Amsterdam around 1642, which brought him around 19.000 guilders, were charged 1 percent or 5 percent was apparently not clear (Peltzer, Joachim van Sandrarts [note 15], 417).

${ }^{34}$ Van Eeghen, "Uitdraagsters" (note 33).

${ }^{35}$ For more recent commentary, see Ekkart and Ornstein-van Slooten, Oog inOog(note 25), cats. 45-49. The authors have no doubt about the identification of "young Haringh" as Pieter, the delegate of the Orphan Chamber.

${ }^{36}$ For more recent scholarship on Rembrandt's bankruptcy, see P. Crenshaw, Rembrandt's Bankruptcy (Cambridge: Cambridge University Press, 2006).

${ }^{37}$ Advertisement, Haerlemsche Courant, 20.12.1670, sale of works on paper, according to handbills (bijletten) to begin on December 19 (Unger, J.H.W., "Vondeliana II, Vondel's Handschriften,"Oud Holland2 [1884]: 114n)

${ }^{38}$ Noordkerk, Handvesten (note 2).

${ }^{39}$ M. M. KleerkooperandW. P. van Stockum, De boekhandel te Amsterdam voornamelijk in de 


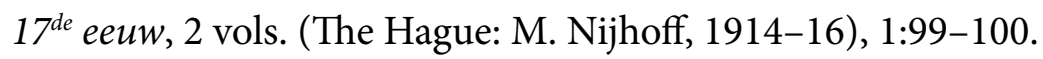

${ }^{40}$ [Text reproduced exactly from the original Dutch] Gerrit Jacobsz Haringh erfhuizen: 1.3.1607 Gillis van Conincksloo, 13.6.1608 idem, 26.5.1609 N.N., 14.3.1611 Barchman Claesz, 20.3.1612 Crispiaen Colijns, 28.8.1612 Claes Rauwert, 30.10.1613 Samuel Godijn, 8.11.1613 Anthonic Boomhoff, 7.4.1614 Cornelis van der Voort, 21.4.1614 Lieven Heylinc,zonder datum (voorin) Jacque Kina, 24.4.1617 Marritje Walichs, 27.4.1617 Andries de Graeuw,31.5.1617 Barent Gerritsz, 10.3.1616 (achterin) Jan Martsz Smul, 9.4.1620 Anthony van Zurick,24.8.1621 Abraham en Victoria Vinx, 13.7.1623 dr. Goswynus van der Hal en Hendrickgen Hendricx,zijn vrouw, 20.3.1625 Jacob Claesen van Hoorn en Weyntgen van Neck, 19.4.1625 Barbara Jacobs, 13.5.1625 Cornelis van der Voort, 30.8.1625 Cornelis van der Voort, met als toevoeging enkele van Pieter van der Voort, 29.1.1626 Govert Boelisz en Lazarus Lazarus, 15.1.1628 Cornelis en Jan Witsz,15.1.1628 ten verzoeke ran Pieter Pietersz schilder van wegc Cornelis Jansz Schoneman, 15.1.1628 Mr. Jan Engels.

Gerrit Jacobz Haringh willige verkopingen: 30.9.1608 Johanna Artsen en Jaques van der Lamcn, 2.10.1608 Felix van Lun, 29.10.1608 Valerius van der Houven, 23.2.1609 N.N., 24.2.1609 Pieter Loduwijcxs, 20.5.1609 Claas Eewouts, 23.5.1609 Valerius van der Houven, 16.3.1610 Lucas Lus, 15.4.1610 Cornelis van der Voort.

Jan Dircksz van Beuningen erfhuizen: 16.10.1619 Gerrit de Back, 16.10.1619 Dirck Gerritsz in de Swarte Cater, 6.4.1620 Paulus Bisschop, 15.8.1620 Salomon de schilder, 29.8.1620 Salomon Pietersz, 5.9.1620 idem, 2.4.1621 Dr. Claes Bourgoigne, 13.4.1621 Jan Jansz schilder, 13.5.1621 Marten Hendricx Spiegel, 12.5.1621 Elbert Martsz, 16.9.1622 Salomon Pietersz, Claes Cornelissen en Pieter Claesz de drager, 3.12.1624 Cathelijn Biscops, wed. Pieter Heseman, 15.1.1625 Christoffel van Sichem, 19.3.1625 Hendrick Hoeffslager, 17.7.1625 Jan van Gansepoel, 23.9.1625 Cornelis de Bruyn, 27.9.1625 idem,

18.10.1625 N. N. kistenmaker, Salomon Hendricx, 20.10.1625 weduwe Dirck van Nes, 22.4.1626 Johannes Paracelsis, 25.4.1626 Anna van der Laen, 15.7.1626 advocaat Schot, 22.9.1626 Pieter Ysacksen. (N.B. de laatste vier vermoedelijk willige verkopingen).

Daniel Jansz van Beuningen erfhuizen: 22.6.1627 Louis Rotkoert, 7.11.1628 ten verzoeke Jan Braems (crachter: Dit is geen weescamer), 8.11.1628 Lazarus Wateringh en Swaentgen Gerrits, 5.12.1629 Cornelis van den Black, 22.2.1635 Barent van Someren, 26.5.1635 Pieter Janssen van Loo en Cathelijn Ingenraem, 10.7.1635 Hans Wijnantsz, 7.7.1636 Michiel Kuypers, 18.8.1636 Arent Jansa en Annetje Harmans verkoping lijsten, 9.3.1637 Jan Basse, 7.4.1637 Pieter le Febvre, 10.9.1637 Nicolaas Bas, 30.9.1637 Jan van Maerlen en Maria van Geels, 27.10.1637 idem, 9.2.1638 Gommert Spranger.

${ }^{41}$ SAA, no. 5032, Groot Memoriaal III 258.

${ }^{42}$ [Text reproduced exactly from the original Dutch] Gerrit Jansz Block: 3.4.1603 Claes Pietersz schoolmaster (met los vel met opgaaf van boeken).

Gerrit Jacobsz Haringh erfhuizen: 26.11.1605 Elbert Boelisz., 15.7.1606 Willem Nes boekdrukker, 27.2.1608 Isaack Verbeeck, 27.1.1609 Joost van Loo schoolmeester en Sara van Loo, zijn vrouw, 7.3.1613 Gerrit Henricksz Breugel (boeken en letters), 12.3.1613 Barent Adriaensen, 22.9.1616 Joris Gerits Nachtegael (boeken en letters), 28.9.1616 Johannes Cramerius.

Gerrit Jacobsz Haringhwillige verkopingen: 11.10.1608 N.N. in the Schoolsteegje (boeken en letters), 9.4.1609 Esaias van Someren (boeken en papier), Michiel Colijn and Sacharias Heyns, 3.4.1610 Willem Jansz Buys, 17.4.1610 Grietje Pieters (boeken, bijbels, letters en papier). Jan Dircxsz van Beuningen erfhuizen: 24.1.1618 Pieter Rutten, 2.2.1618 Jan Gerritsz boek verkoper 
op de Dam in de kas, 18.3.1625 Arnoldus Magistri Glaseri, 18.2.1626 Antony Smijters schoolmeester, 19.2.1626 Hugo Petit and Jan Thiel.

Daniel Jansz van Beuningen erfhuizen: 26.4.1627 Melchior Bouwer, secretaris dezer stad, 4.12.1629 Ds Petrus Pulleus en Aeltje Emmes, 7.4.1637 Pieter le Febvre, 15.3.1638 Michiel Colijn.

${ }^{43}$ I. H. van Eeghen, De Amsterdamse boekhandel 1680-1725 (Amsterdam: Scheltema \& Holkema, 1960), 4:268-69.

${ }^{44}$ For Hendrick Lourisz, see S. A. C. Dudok van Heel, "Als Justus van Maurik dit eens had geweten: Zes eeuwen geschiedenis van Damrak nr. 49, deel 2," Jaarboek Amstelodamum 80 (1988): 26-34.

${ }^{45}$ SAA, no. 5032, Groot Memoriaal IV 154vo and v, before 157vo.

${ }^{46} \mathrm{H}$. Floerke, Studien zur Niederländischen Kunst- und Kulturgeschichte: Die Formen des Kunsthandels, das Atelier und die Sammler in den Niederlanden vom 15-18 Jahrhundert (Munich: G. Müller, 1905). See also Eric Jan Sluijter, "On Brabant Rubbish, Economic Competition, Artistic Rivalry, and the Growth of the Market for Paintings in the First Decades of the Seventeenth Century," Journal of Historians of Netherlandish Art 1, no. 2 (2009) http://jhna.org/index.php/ past-issues/volume-1-issue-2/109-on-brabant-rubbish

${ }^{47}$ Bredius, Künstler- Inventare (note 18), vol. 6 (1919): 2174.

${ }^{48}$ SAA, Familiearchief Backer, no. 454.

${ }^{49}$ SAA, no. 366, Gildenarchief, 4.2 , no. 80 , present at the library of the association for the advancement of the interests of the book trade. Some of these requests are -- in rather incomplete form -- also mentioned by Kleerkooper and van Stockum, Boekhandel (note 40) in their discussion of the booksellers involved.

${ }^{50}$ RA 729 (Besogneboek)

${ }^{51}$ SAA, Familiearchief Backer, Tracas judiciaires, 38-39.

${ }^{52}$ Christopher White, with assistance from J. M. Komter and H. F. Wijnman, Rembrandt (The Hague, 1964).

${ }^{53}$ SAA, no. 5032, Groot Memoriaal IV 23vo.

${ }^{54}$ SAA, no. 366, Gildenarchief, 4.1, 56, p. 12 etc., present at the library of the association for the advancement of the interests of the book trade. The names of those listed on February 15, 1664, are as follows: Jan Bruinen, Salomon Savery, David Tartas, Judick Dircks, Jacob de Mey, Johannis Baucquius (or Berucquius), Vrederick de Wit, Huigh Allart, Justus Danckerts, Nicolaas Visscher, Klement de Jonghe, Jan Kralinghe, Mathias Wynekes, Jan Robbertsz, Alexander Jansz, Jan de Vries, Geestevelt, Jan Jansz Ratelbant, Herman Gerritsz, Antoni Dircksz, Christoffel Conradus, Thymon Houthaack, Abraham Latham, Willem Schijf, and Rolof Labato.

${ }^{55}$ For a recent general survey on printsellers, see E. Kolfin, "Amsterdam, stad van prenten. Amsterdamse prentuitgevers in de $17^{\text {de }}$ eeuw," in Gedrukt to Amsterdam: Amsterdamse prentmaker en -uitgevers in de gouden eeuw, exh. cat., edited by E. Kolfin and J. Van der Veen (Amsterdam: Museum het Rembrandthuis, 2011), 10-57; on the Danckerts family, see J. Van der Veen, "Danckerts en zonen. Prentuitgevers, plaatsnijders en kunstverkopers te Amsterdam, ca. 1625-1700," in Gedrukt to Amsterdam, 58-119; on Salomon Saverij, see J. Hillegers and L. Jaeger, "Salomon Saverij, een plaatsnijder en zijn vrienden," in Gedrukt to Amsterdam,, 120-63.

${ }^{56}$ The bill of March 27, 1680, by notary J. Backer gives some details. On March 12, 1679, Johannes Wijmer, the servant of Saint Luke's Guild, received as salary 15 guilders; the sale was thus between February 11, the day the inventory was made up by the notary Backer, and March 12, and it must have covered ten days. On June 14, the auctioneer De Blocq paid out for sold copper plates, etc. 
15.000 guilders and on October 25, 1679, 2138 guilders. It appears from a deed of April 23, 1667, by notary A. van de Ven, concerning the estate sale of Danckert Danckerts (and of course with the booksellers' guild servant attending), that the same auctioneer was apparently disputing with De Jonghe over the contents of a sale of woodcuts and copper plates by Scamozzi, so that the auctioneer finally had them assigned to another bidder.

${ }^{57}$ Kleerkooper and van Stockum, Boekhandel (note 40), 1: 4.

${ }^{58}$ Kleerkooper and van Stockum, Boekhandel (note 40), 2:911-14.

${ }^{59}$ For the history of the Guild of Saint Luke and the art trade in the eighteenth century, see the publications of Oldewelt, "Sint Lucasgilde" (note 10), and Bille,De tempel der kunst (note 29); for the history of the booksellers' guild in the seventeenth and eighteenth centuries, see Van Eeghen, "Het boek- en konstverkopers-, nevens boek-, kaart- en plaatdrukkers- en boekbindersgilde," in Van Eeghen, De gilden (note 6), 100-30, where one can find details concerning the engravers, who remained with the Guild of Saint Luke.

\section{Bibliography}

\section{Archival Sources:}

Stadsarchief Amsterdam (SAA) http://stadsarchief.amsterdam.nl/archieven/archiefbank/inventarissen/index.nl.html

Archief van de Burgemeesters, Poorterboeken

Archief Burgerweeshuis

Des Boedelskamer (Desolate Boedelskamer)

Familiearchief Backer

Groot Memoriaal.

Weeskamer

Gildearchief

Rechterlijk Archief (RA)

\section{Printed Primary Sources:}

Bredius, A. Künstler- Inventare; Urkunden zur Geschichte der Holländischen kunst des XVIten, XVIIten und XVIIIten Jahrhunderts. 8 vols., The Hague, 1915-22.

Dillen, J. G. van. Bronnen tot de geschiedenis van het bedrijfsleven en gildewezen van Amsterdam. 3 vols. The Hague, 1929-74. 
Hofstede de Groot, Cornelis. Die Urkunden über Rembrandt (1575-1721).The Hague: M. Nijhoff, 1906.

Noordkerk, H. Handvestenofte Privilegien ende Octroyen: Mitsgaders Willekeuren, Costuimen, Ordonnantien en Handelingen der stad Amstelredam:Door Last Van De Edele Groot-Achtbaare Heeren Burgermeesteren en Regeerders Van Dezelve Stad Tot Den Eersten February 1747 Vervolgt, Met Verfcheide Stukken Vermeerdert Mitsgaders in Eene Andere Fchikking Gebragt; En Met De Nodige Registers Voorzien. Eerst-[derde] Stuk. 5 vols. Amstelredam: H. van Waesberge, S. en P. Schouten, 1748-78.

Obreen, Frederik D. O. "Het Sint Lucasgild te Amsterdam." In Archief voor Nederlandsche Kunstgeschiedenis, 3: 89-196. (7 vols.) Rotterdam, 1877-90.

\section{Secondary Sources:}

Backer, J. F. "Les tracas judiciaires de Rembrandt." Gazette des Beaux-Arts 66 (1924): 38-39.

Bakker, P. "Crisis? Welke crisis? Kanttekeningen bij het economisch verval van de schilderkunst in Leiden na 1660." De Zeventiende Eeuw 27, no. 2 (2011): 232-69.

Bemmelen, J. F. van. “Identificatie van familie-portretten.” Jaarboek Amstelodamum 26 (1929): 59-78.

. "Het album De Moor." Maandblad De Nederlandsche (1927): cols. 65-73.

Bille, Clara. De tempel der kunst of het kabinet van Braamcamp. Amsterdam: de Bussy, 1961.

Blankert, A. Kunst als regeringszaak. Exh. cat. Amsterdam: Royal Palace, 1975.

Briels, J. Vlaamse schilders en de dageraad van Hollands Gouden Eeuw. Antwerp, 1997.

Bredius, A. “Rembrantiana.” Oud Holland 28 (1910): 193--204.

Crenshaw, Paul. Rembrandt's Bankruptcy. Cambridge: Cambridge University Press, 2006.

Dawn of the Golden Age: Northern Netherlandish Art 1580-1620. Exh. cat. Edited by G. Luijten et al. Amsterdam: Rijksmuseum, 1993.

Dudok van Heel, S. A. C. “De Kunstboeken van Adriaen Hendricx de Wees." Maandblad Amstelodamum 66 (1979): 43-44.

. “Jan Pietersz Zomer (1641-1724), makelaar in schilderijen (1690-1724).” Jaar-

boek Amstelodamum 69 (1977): 89-106.

. “De schilder Claes Moyaert en zijn familie.” Jaarboek Amstelodamum 68 (1976):

39-40. 
.Als Justus van Maurik dit eens had geweten: Zes eeuwen geschiedenis van Damrak nr. 49, deel 2." Jaarboek Amstelodamum 80 (1988): 26-34.

Eeghen, I. H. van. De Amsterdamse boekhandel 1680-1725. Amsterdam: Scheltema \& Holkema, 1960.

. "Het Amsterdamse Sint Lucasgilde in de 17de Eeuw." Jaarboek van het Genootschap Amstelodamum 61 (1969): 65-102.

. "Schilders of Sint Lucasgilde." In Inventarissen der archieven van de gilden en van het brouwerscollege, 103-8. Archief der Gemeente Amsterdam, 1951.

ber 1969): 102-10.

. "Uitdraagsters 'tzij man of vrouw." Maandblad Amstelodamum (August-Septem. De gilden: Theorie en praktijk. Bussum: C. A. J. van Dishoeck, 1974.

. "Het boek- en konstverkopers-, nevens boek-, kaart- en plaatdrukkers- en boekbindersgilde," in Van Eeghen, De gilden (see above), 100-30.

“Een belangrijke ontdekking." Architectura 21 (1913): 339-40.

Ekkart, R., and E. Ornstein-van Slooten. Oog in Oog met de modellen van Rembrandts portret-etsen/Face to Face with the Sitters for Rembrandt's Etched Portraits. Exh cat. Amsterdam: Museum het Rembrandthuis, 1987.

Elias, Johan E. De Vroedschap van Amsterdam. 2 vols. Haarlem: Loosjes, 1903/5.

Floerke, H. Studien zur Niederländischen Kunst- und Kulturgeschichte: Die Formen des Kunsthandels, das Atelier und die Sammler in den Niederlanden vom 15-18 Jahrhundert. Munich: G. Müller, 1905.

Fremantle, Katharine. "Cornelis Brise and the Festoon of Peace." Oud Holland 69 (1954): 222-28.

Gedrukt to Amsterdam: Amsterdamse prentmaker en -uitgevers in de gouden eeuw. Exh. cat. Edited by E. Kolfin and J. Van der Veen. Amsterdam: Museum het Rembrandthuis, 2011.

Hillegers, J., and L. Jaeger. "Salomon Saverij, een plaatsnijder en zijn vrienden." In Gedrukt to Amsterdam (see above), 120-63.

Jaarboek van het Centraal Bureau voor Genealogie en het Iconographisch Bureau7 (1953): 15-81.

Kleerkooper, M. M., and W. P. Van Stockum Jr. De Boekhandel te Amsterdamvoornamelijk in de $17^{e}$ eeuw,. 2 vols. The Hague: M. Nijhoff: 1914-16. 
Kolfin, E. "Amsterdam, stad van prenten: Amsterdamse prentuitgevers in de 17de eeuw." In Gedrukt to Amsterdam (see above), 10-57.

Lugt, Frits. Les marques de collections de dessins et d'estampes. Amsterdam, 1921.

Oldewelt, W. F. H. “Rembrandt' etsen 'de oude’ en 'de jonge Haringh.” Jaarboek Amstelodamum 27 (1930): 175-78.

. "Het St. Lucasgilde.” In Oldewelt, Amsterdamsche Archiefvonsten,84-91. Amster-

dam, 1942.

. “Een beroepstellung uit den jare 1688." In Odewelt, Amsterdamsche Archiefvonsten, 172-76.Amsterdam, 1942.

Peltzer, A. von. Joachim von Sandrarts Academie der Bau-, Bild- und Mahlerey-Künste von 1675: Leben der berühmten Maler, Bildhauer und Baumeister. Munich, 1925.

Roever, N. de. "Pieter Aertsz, gezegd lange Pier, vermaard schilder." Oud Holland7 (1889): 1-38.

Scheltema, Pieter. Rembrand: Redevoering over het leven en de verdiensten van Rembrand van Rijnmet eene menigte geschiedkundige bijlagen meerendeels uit echte bronnen geput. Amsterdam: P.N. Van Kampen, 1853.

. "Schilders die te Amsterdam poorters zijn geworden, tusschen de jaren 1584 en 1605.” In Obreen, Archief voor Nederlandsche Kunstgeschiedenis (see above), 2:272-75.

. "Namen der schilders, die in de tweede helft der zeventiende eeuw te Amsterdam poorters zijn geweest." Aemstel's Oudheid 4 (1861): 59-70.

Sluijter, Eric Jan, “On Brabant Rubbish, Economic Competition, Artistic Rivalry, and the Growth of the Market for Paintings in the First Decades of the Seventeenth Century." Journal of Historians of Netherlandish Art 1, no. 2 (2009) http://jhna.org/index.php/past-issues/volume-1-issue-2/109on-brabant-rubbish

Strauss, Walter L., and Marjon van der Meulen, with the assistance of S. A. C. Dudok van Heel and P. J. M. de Baar. The Rembrandt Documents. New York: Abaris Books, 1979.

Unger, J. H. W. “Vondeliana II, Vondel's Handschriften.” Oud Holland 2 (1884): 111-134.

Van der Veen, J. "Danckerts en zonen. Prentuitgevers, plaatsnijders en kunstverkopers te Amsterdam, ca. 1625-1700." in Gedrukt to Amsterdam (see above), 58-119.

White, Christopher, with assistance from J. M. Komter and H. F. Wijnman. Rembrandt. The Hague, 1964. 
Recommended Citation:

I.H. van Eeghen (Jasper Hillegers, translator), "The Amsterdam Guild of Saint Luke in the 17th Century," JHNA 4:2 (Summer 2012), D0l:10.5092/jhna.2012.4.2.4 